NBER WORKING PAPER SERIES

\title{
INTERNATIONAL BORROWING, CAPITAL CONTROLS AND THE EXCHANGE RATE: LESSONS FROM CHILE
}

\author{
Kevin Cowan \\ José De Gregorio \\ Working Paper 11382 \\ http://www.nber.org/papers/w11382
}

\author{
NATIONAL BUREAU OF ECONOMIC RESEARCH \\ 1050 Massachusetts Avenue \\ Cambridge, MA 02138 \\ May 2005
}

Presented at the NBER Conference "International Capital Flows," Santa Barbara, CA, December 2004, and forthcoming in an NBER book to be published by Chicago University Press. We thank (without implicating) Ricardo Caballero, Guillermo Calvo, Arturo Galindo, Alejandro Micco, Luis Oscar Herrera and Aaron Tornell for helpful comments to a previous version of this paper. We also very grateful to Erwin Hansen, Danielken Molina and Marco Nuñez for excellent research assistance. The views expressed in this paper are our own and do not necessarily represent those of the institutions with which we are affiliated. The views expressed herein are those of the author(s) and do not necessarily reflect the views of the National Bureau of Economic Research.

(C2005 by Kevin Cowan and José De Gregorio. All rights reserved. Short sections of text, not to exceed two paragraphs, may be quoted without explicit permission provided that full credit, including $@$ notice, is given to the source. 
International Borrowing, Capital Controls and the Exchange Rate: Lessons from Chile

Kevin Cowan and José De Gregorio

NBER Working Paper No. 11382

May 2005

JEL No. E51, F31, F32, F34, F41

\section{ABSTRACT}

This paper analyzes the Chilean experience with capital flows. We discuss the role played by capital controls, financial regulations and the exchange rate regime. The focus is on the period after 1990, the period when Chile returned to international capital markets. We also discuss the early 80s, where a currency collapse triggered a financial crisis in Chile, despite stricter capital controls on inflows than the 90s and tighter currency matching requirements on the banking sector. We conclude that financial regulation and the exchange rate regime are at the center of capital inflows experiences and financial vulnerabilities. Rigid exchange rates induce vulnerabilities, which may lead to sharp capital account reversals. We also discuss three important characteristics of the Chilean experience since the 90s. The first is the fact that most international borrowing is done directly by corporations and it is not intermediated by the banking system. The second is the implication of the free trade agreement of Chilean and the US regarding capital controls. Finally, we examine the Chilean experience following the Asian-Russia crisis, showing that Chile did not suffer a sudden-stop, but a current account reversal due to policy reactions and a sudden-start in capital outflows.

Kevin Cowan

Inter-American Development Bank

1300 New York Avenue

Washington, DC 20577

kevinco@iadb.org

Jose De Gregorio

Banco Central de Chile

Agustinas 1180

Santiago, Chile

jdegrego@bcentral.cl 


\section{Introduction}

This paper discusses Chile's experience with international borrowing over the last two decades. This period allows us to contrast the Chilean experience during two recent episodes of capital flows to Latin America: the late 70s and the 90s. The first episode ended in disaster for Chile, with a Balance of Payments and financial crisis, and huge costs in terms of output and employment. Unlike other countries in the region, the crisis was not caused by fiscal imbalances, but triggered by a deteriorating international environment, a misaligned exchange rate and a weak financial system. Indeed, it started before Mexico announced that it could not meet its foreign obligations, which ignited the debt crisis. In many aspects the Chilean crisis of the early 80s resembles the more recent Asian crises, and the so-called "twenty-first century crises."

During the second episode of capital inflows Chile fared much better, and managed to avoid the large financial collapses that afflicted many other emerging economies during this period. Following the 1980s crisis Chile experienced a sharp recovery, and between 1990 and 1997 was the recipient of massive capital inflows. During this period, and in order to stem net inflows, avoid a large appreciation and keep control of monetary policy, the authorities implemented capital controls on inflows and liberalized outflows. The most widely cited control was the unremunerated reserve requirement (URR) on capital inflows, the encaje. ${ }^{1}$ Because of the resiliency of the Chilean economy to the events following the tequila crisis in Mexico and the Asian-Russian crisis of the late 90s this policy has received a lot of attention in both academic and policy circles. Finally, after mounting currency pressures in 1998 and a recession in 1999 capital controls were eliminated.

The late 70 s and early 80 s provide a good control group against which to evaluate the financial integration and macroeconomic developments of the Chilean economy during the 90s. For a start, capital controls on inflows were much stricter before the 1982 crisis than during the 90s. In addition, financial regulation requiring banks to match the currency composition of their income and liabilities to avoid exposure to exchange rate risk was very similar in 1982 to that in place in the 1990s. Neither avoided the collapse of the corporate sector, which in turn contaminated the financial system. Clearly explanations for the lower

\footnotetext{
${ }^{1}$ We use indistinctly URR and encaje.
} 
vulnerability of the Chilean economy must lie beyond capital controls and mismatch regulation.

In this paper we argue that the resilience of the Chilean economy during the 90s was mainly due to: (i) changes in banking regulation that promoted a solid financial system (in particular changes in regulation for related lending) and, (ii) to the absence of currency risk guarantees to the private sector. These in turn induced more prudent indebtedness policies by corporations, which as a result were well equipped to tolerate the exchange rate fluctuations of the late 90s. We argue in the paper that a rigid exchange rate system contributes to capital inflows by reducing the risk of arbitraging existing interest rate differentials. There is no evidence that capital controls were able to reduce these inflows, although there is evidence that they had a limited effect on the composition of these flows.

In a nutshell, we conclude that flexibility in exchange rate management and a sound financial system are more important than capital controls in protecting the economy from external shocks and fluctuations in the availability of international capital.

There are a series of additional characteristics of Chile's international borrowing that are worth examining. One of these is the secondary role played by the banking sector in intermediating foreign credit. In contrast other countries with similar levels of economic development, non-financial corporations did most of the international borrowing in Chile during the 90s. We do not have arguments to say whether this is a positive or negative development. On the one hand it isolates the financial system from financial turmoil. On the other hand it limits access of smaller firms to foreign funds. This second aspect becomes more important in the presence of a solid financial system.

Finally, there is the issue of whether Chile can introduce capital controls after signing a free trade agreement with the US. Although there is some loss of degrees of freedom to apply controls, the option, although limited, still remains.

The paper proceeds as follows. The second section describes foreign debt and the international investment position for Chile over the last quarter century. Section 3 discusses the issue of capital controls, focusing on the effects of the unremunerated reserve requirement, the encaje. We explore a new issue, namely the composition between financial and non-financial borrowing. We show, from an international perspective, that while capital controls were in place in Chile the composition of external debt tilted toward 
the non-financial sector. Then, section 4 follows with a discussion on banking regulation and international borrowing. As we argue, the exchange rate regime is the key, and the examination of the effects of exchange rate regimes on debt inflows in the $90 \mathrm{~s}$ are discussed in section 5, whilst section 6 focuses on currency mismatches. Section 7 discusses the implications for Chile of the recently signed free trade agreement with the US. Finally, section 8 analyzes the Chilean experience following the Asian-Russia crisis, where we dispute the view that Chile had a sudden stop. As we discuss in the section, Chile had a current account reversal due to an initially large current account deficit and a negative terms of trade shock, which induced the authorities to follow a very tight monetary policy and a strong defense of the peso. We conclude that from the capital account point of view, the reversal was a sudden-start of outflows rather than a sudden-stop of capital inflows. Section 9 concludes.

\section{Stylized Facts}

In this section we provide an overview of the evolution of Chilean international borrowing and capital flows. We start with the early eighties, as this period provides a good (or a bad) benchmark against which to evaluate the evolution of international financial integration during the 90 s.

\subsection{The Evolution of External Debt}

Prior to the debt crisis of 1982 Chile's external debt was approximately 14 billion dollars, slightly less than 50\% of GDP (figures 1 and 2). Then, between 1982 and 1985, external debt grew moderately in dollar terms, but sharply in terms of GDP as a result of the depreciation of the Chilean peso and a large fall in output during the debt crisis. External debt peaked at $120 \%$ of GDP in 1986. In the second half of the 80s Chile's external debt remained relatively stable in dollar terms, while output growth helped bring the debt to GDP ratio down to 60\% of GDP by 1989.

As a result of renewed access to international capital markets external debt went from 21 billion dollars at the beginning of the 90s to 35 billion dollars in 1999. Most of this growth took place in the second half of the decade. In recent years, debt has continued to grow in dollar terms, reaching 43 billion dollars in December 2003. Although foreign 
debt has doubled in dollar terms since 1990 as a fraction of GDP it still remains below its 1989 level.

Prior to the debt crisis, most of Chile's external debt was private (about 60\%). Following the crisis, and in order to successfully renegotiate external debt, private debt received public guarantees. In addition, most of new foreign borrowing was done by the public sector. This caused a large drop in the share of private debt, which bottomed out at $17 \%$ of total external debt in 1987 . Later, Chile's return to international financial markets and voluntary lending combined with sound public finances (the fiscal accounts where in surplus until 1999) drove the share of the private sector in total external debt up $84 \%$ in 2000. Subsequently, as a result of the slow down in economic activity and mild fiscal deficits, the share of public debt has increased slightly, rising from $16 \%$ of the total stock in 2000 to $20 \%$ in 2003.

Another characteristic of Chilean private sector external debt is that most of it is non-financial (figure 3), i.e. not intermediated by the domestic financial system. Firms borrow directly from abroad, skipping the domestic financial system. Caballero et al. (2004) stress this point when comparing Australia and Chile, and their relative resilience to external shocks. In the case of Australia, banks do most of the foreign borrowing, which is then is intermediated to the domestic economy. Accordingly, Caballero et al. (2004) argue that international borrowing done by banks allows access to international capital markets to a broader set of borrowers, which may in turn explain Australia's different response to the large negative terms of trade shocks following the Asian crisis.

This has not always been the case. In 1975, as Chile began opening to international capital markets, private debt was only 786 million dollars. Because of severe restrictions on foreign borrowing by domestic banks (discussed in detail below), only $20 \%$ of this private debt was financial. Restrictions on international borrowing for domestic banks were gradually lifted during the late 70 s and early 80 s, and private debt grew massively, specially banking debt. In 1981 private external debt was close to 10 billion dollars, two thirds of which was owed by the banking system.

Foreign borrowing by the domestic banking system and the mismatches it generated was at the center of the financial crisis of 1982. Interestingly, it was not the banks that were mismatched, but their corporate borrowers. Banks were forced to lend in foreign 
currency all that they had borrowed in foreign currency (Edwards and Cox-Edwards, 1991). The result was large dollar denominated bank debts in the balance sheets of domestic firms, many of which operated in the non-tradeable sector.

\subsection{The Evolution of the International Investment Position}

Chile's foreign liabilities in 1980 were about 16.5 billion dollars, out of which 12.7 billion dollars corresponded to external debt and the rest to foreign direct investment (figure 4 and table 1$)^{2}$. Most of the liabilities were in the form of external debt, the standard pattern of capital flows prior to the debt crisis. The composition of foreign liabilities started to change in the late $80 \mathrm{~s}$ and early $90 \mathrm{~s}$, when foreign direct investment started to play a much more important role. While in 1985 total foreign direct investment represented $15 \%$ of total liabilities, in 1990 its share was up to 34\%, and currently it represents 53\%. External debt, in contrast, has reduced its importance, falling from close to two-thirds in 1990 to less than half in 2002. Portfolio investment makes up only $13 \%$ of total liabilities.

From 1990 to 2002 total external liabilities increased from 31 to 84 billion dollars. As shown in figure 5, foreign assets also increased significantly during this period, rising from 16 to 56 billion dollars. As a result, the net liability position (line IIP in the figure) has grown by considerably less than total foreign liabilities, remaining between 35 and $45 \%$ of GDP since 1990. On the other hand, financial integration (measured as the sum of assets and liabilities over GDP) has increased substantially during the 1990s, rising from 140\% of GDP in 1990 to $206 \%$ in 2002.

An important development regarding Chile's international investment position is the increased relevance of pension funds in international assets. Pension funds have gradually been allowed to increase the foreign share of their portfolio, so that currently about $30 \%$ of total pension funds are invested abroad (figure 6). Because of the size of the accumulated savings in the funds-- about $50 \%$ of GDP-- this has made a significant difference in the

\footnotetext{
${ }^{2}$ The figures on the international investment position being constructed by the IMF are divided into foreign direct investment (FDI), portfolio investment and other. In the liability side most external debt is included in "other", but in the other items part of debt is also include. For example, debt associated with FDI projects are
} 
composition of the country's international assets, which shows up in portfolio investment in the assets side of table 1. The logic for the gradual opening up of the investment abroad by pension funds was two-fold. On the one hand, lifting restrictions allowed for greater portfolio diversification. On the other it was initially meant to encourage capital outflows in a period of continuous real exchange rate appreciation ${ }^{3}$.

Although its net international investment position is similar to that of other emerging markets Chile is more financially integrated (figure 7). In terms of composition of assets, Chile has more portfolio investment than other emerging markets, mainly because of the activity of pension funds. It has also more reserves. In terms of liabilities the share of FDI in Chile is one of the largest amongst emerging markets and high-income economies. External debt as fraction of GDP is slightly larger than that of emerging markets and significantly less than that of advanced economies. Another important characteristic of Chile's recent international borrowing is that foreign companies owe most external debt. Indeed, in 2002 foreign companies owed $57 \%$ of total private debt. This shows that degrees of vulnerability of Chile are much less than those indicated by external debt figures. ${ }^{4}$

\section{Capital Controls: The encaje}

Following the surge in capital flows to emerging markets in the early 90s, Chilean authorities imposed controls on capital inflows while gradually liberalizing capital outflows. ${ }^{5}$ The stated purpose of this policy was to reduce net inflows and stem the appreciation of the Chilean peso.

The main instrument used to limit inflows, widely discussed in policy circles, was an unremunerated reserve requirement known as the encaje. The encaje required that a

included in FDI, while bond issuance by residents are included in external debt figures, but in international investment statistics is part of portfolio investment since they are tradeable instruments.

${ }^{3}$ The exchange rate pressures of the outflows of pension funds has been minor, since by regulation they must have low currency exposure, so that in practice they have been investing abroad fully hedging their currency exposure. This is one of the factors behind the development of the FX derivative market in Chile (De Gregorio and Tokman, 2004).

${ }^{4}$ For further details see Jadresic et al. (2003).

${ }^{5}$ As part of the effort to increase outflows, years required for foreign investors to remit capital and profits were slowly reduced and finally eliminated. Pension funds limits to invest abroad were also widened. For details on the main measures taken since 1990 see Appendix 1. See also Gallego et al. (1999). 
fraction of the capital inflow be deposited in a non-interest bearing account in the Chilean Central bank. The encaje was introduced in June 1991, and was expanded and extended various times in the following years. Initially, it was set at $20 \%$ of the inflow, for a period from 3 months to 12 months depending on the maturity and the nature of the credit. Trade credit was excluded from the encaje ${ }^{6}$. Later, in 1992 and then in 1995, the base was broadened to include foreign currency deposits and the proceeds from the issuance of ADR's (American Depository Receipts), the rate was increased to 30\%, and the period was set at 12 months regardless of the term of the credit. The encaje was reduced and finally eliminated in $1998 .^{7}$

There were several reasons given for introducing the encaje. The most prominent was the need to reduce net capital inflows to prevent an appreciation of the Chilean peso. Indeed, a depreciated real exchange rate was considered a key factor behind the successful recovery of the economy that had taken place since the mid 1980s. In addition, it was argued that capital controls would allow for some degree of monetary policy independence in the context of a managed exchange rate, which for most of the 90s was an exchange rate band with adjustable width and a crawling central parity (figure 8). Finally, since the cost of the encaje was proportionally higher for short-term inflows, it was argued that it would reduce the vulnerability of the economy to "hot capital".

An assessment of the macroeconomic consequences of the encaje requires looking at its effect on: interest rates, level and composition of capital flows and the exchange rate. ${ }^{8}$ We review existing evidence on the effects of the encaje on all of these variables in this section.

\subsection{Macroeconomic Effects}

\section{Interest Rates}

In theory the existence of an encaje should allow for differences between domestic and foreign interest rates without inducing capital flows to restore a non-arbitrage

\footnotetext{
${ }^{6}$ De Gregorio et al (2000) argue that the encaje gradually lost power, as markets came up with ways to circumvent it. The most obvious way to overcome the encaje, frequently cited but not quantified, was to register short-term credit as trade credit.

${ }^{7}$ Before its elimination the rate of the reserve requirement was set to zero.
} 
condition. Assuming full compliance, and an international interest rate of $7 \%$, a $30 \%$ encaje for a year leads to a differential of about 3 percentage points on a one-year inflow. In practice, however, the impact on interest rates is likely to be considerably smaller - as agents switch to longer maturities or find ways of circumventing the encaje.

What then are the empirical estimates of the effect of the encaje on domestic interest rates? Using a VAR framework, De Gregorio et al. (2000) found that the effect on the interest rate was both small and short lived. In the first 6 months after a change in the encaje regulation - which the authors interpret as closing an existing loophole - they find effects that range between 90 and 150bp for a 30\% encaje. This effect dies out slowly over a 12-month horizon. This result lies at the upper range of the estimated effects of the controls on interest rates in Chile. Smaller effects are reported in Edwards (1999), while Gallego et al. (1999) found no effects whatsoever.

\section{Level of Inflows}

The Chilean economy received massive capital inflows during the 1990s, and there is no solid evidence showing that they would have been substantially larger if the encaje had not been implemented. Indeed, most existing empirical studies find no effects of the encaje on the level of capital inflows. The only exception is a study by Gallego et al. (1999), who find that a $100 \mathrm{bp}$ increase in the cost of the encaje reduces total capital inflows by $1 \%$ of GDP. In addition, they find that those flows directly affected by the encaje would decline by $2 \%$ of GDP, which indicates that the composition across maturities of international borrowing was affected. It is important to note that this effect is computed for the stock of foreign liabilities. Given that the total cost of the encaje, using the estimates of Gallego et al. (1999), was on average between 100 and $200 \mathrm{bp}$, the reserve requirement reduced total inflows by at most $2 \%$ of GDP. This is relatively small, considering that total net inflows during the whole period from 1991 until 1997 were approximately $27 \%$ of GDP.

\footnotetext{
${ }^{8}$ The review of the evidence is mainly focused on De Gregorio et al. (2000). See also Soto and Valdes-Prieto (1996), Edwards (1999), Gallego et al (1999), and Nadal de Simone y Sorsa (1999).
} 


\section{Composition of Inflows}

By taxing short-term flows more heavily, one would expect that the maturity of capital inflows should increase. Indeed, existing evidence shows that the encaje led to longer-term external debt. As column (1) in table 2 shows, in the mid 1990s, as capital controls were tightened, short-term debt declined sharply as percentage of total debt. According to De Gregorio et al. (2000) the total effect of the encaje on short-term debt would have been between 0.5 and 1 percentage points of GDP, which would have resulted in a lower stock of short-term debt about 600 million dollars.

From a vulnerability perspective it usually makes sense to look at trade credit separately from other forms of short-term credit, as trade credit are advances on exports and therefore less volatile. In the Chilean case, however, this distinction may be blurred by the fact that short-term debt was registered as trade credit as a way of evading the encaje. With this in mind column (3) shows the evolution of an expanded definition of short-term debt that includes trade credit. Here the effects of the encaje, mentioned above, are not that clear. Most of the decline in short-term debt takes place between 1997 and 1999, a couple of years after the encaje was tightened.

\section{Exchange Rate}

During most of the 90s, the nominal exchange rate in Chile was allowed to fluctuate within a band. In several occasions the width as well as the center of the band were adjusted (figure 8). The first change was the widening of the band from $\pm 5 \%$ to $\pm 10 \%$. Later, in 1997 , it was widened again to $\pm 12.5 \%$. The center of the band was adjusted several times, most notably; it was revalued in early 1992, late 1994 and early 1997. Finally, in the eve of the Asian crisis and motivated by fear of floating (Calvo and Reinhart, 2002), the band was narrowed. Several changes finally led to eliminating the band and moving to a flexible exchange rate regime in December 1999. ${ }^{9}$

Both the exchange rate policy and the encaje tried to avoid an appreciation in the context of massive capital inflows. Casual observation suggests that they failed to do so (figure 9). From 1990 until late 1997 the real exchange rate appreciated persistently. The most appreciated level occurred in 1997, a year in which net capital inflows, excluding

\footnotetext{
${ }^{9}$ For further details see De Gregorio and Tokman (2004).
} 
reserves, were $9.1 \%$ of GDP, accumulation of reserves amounted to $3.3 \%$ of GDP and the encaje was in full application.

Of course, the correct counterfactual is to determine the marginal effect of the encaje on the real exchange rate. We turn to this next. The first empirical study on the effects of the encaje (Soto and Valdes-Prieto, 1996), as well as most subsequent work, has focused on determining whether it was effective in avoiding an appreciation of the peso. All of the existing studies mentioned so far in this section - spanning a broad set of measures, periods and empirical specifications -- fail to find an effect of the encaje on the path of the real exchange rate.

\section{Financial Vulnerability}

In 1998 the Chilean peso suffered three rounds of speculative attacks. These turbulences were fought off with large hikes in interest rates and massive intervention in the foreign exchange market. As a result of this intervention, and a series of negative external shocks, in 1999 the economy suffered its first recession in many years. However, the fall in output was small in comparison to other countries that also experienced sudden stops in capital inflows in the late 90s. Furthermore, Chile in 1999 did not face a financial crisis. This has led many observers to argue that the presence of the encaje reduced Chile's external vulnerability and was central to the mild recession. After all, it reduced the share of short-term debt, a variable that many authors have singled out as an important source of financial vulnerability ${ }^{10}$.

The problem with this view is that the magnitude of the estimated effects of the encaje on the level and composition of capital flows during the 90s make it hard to believe that capital controls were central to Chile's economic success during the nineties. Furthermore, Chile's experience in the early 80s shows that, even if capital controls are effective in limiting the share of short term debt, this certainly does not provide a guarantee against currency crises.

\footnotetext{
${ }^{10}$ A recent literature, motivated by events in East Asia, has argued that short term external debt may be an important source of macroeconomic vulnerability. Proponents of this view include Radelet and Sachs (1998) and Chang and Velasco (1999), who argue that excessive reliance on short-term debt leaves emerging-market corporations vulnerable to "financial panic" as in the stylized model of Diamond and Dybvig (1983). In this context, policies like the encaje have the potential to reduce vulnerability by leghthening the tenor of the external debt contracts.
} 
The Chilean 1982 crisis was a full-blown twin crisis (currency and financial). Starting from a closed capital account, legislation passed early in 1974 allowed Chilean non-financial firms and individuals to borrow abroad. However, inflows were restricted to maturities greater than 6 months. In April 1976, and concerned with the destabilizing effects of short-term capital inflows, Chilean authorities further lengthened this minimum maturity to two years. The minimum maturity restriction was to stay in place up to the debt crisis in 1982. In 1979 an additional restriction on short debt was introduced: an unremunerated reserve requirement (an encaje) was put in place on all foreign loans shorter than 65 months. ${ }^{11}$ As a result of these stringent controls, short-term debt in 1981 was only $19 \%$ of total debt. This did not prevent a severe crisis, however, with output declines of $13.6 \%$ in 1982 and $2.8 \%$ in $1983 .^{12}$

\subsection{Microeconomic Effects}

The available evidence shows that, at best, the effects of the encaje on capital inflows, interest rates and the exchange are small. Furthermore, the estimated magnitudes, and the events of 1982, suggest that it is no panacea against currency and financial crisis. So much for the benefits. What about the costs?

\section{Differential Effects Across Firm Size}

The microeconomic distortions that the encaje introduces are an issue frequently ignored in the evaluation of capital controls in Chile. If and when it worked, the main effects of the encaje was to push the domestic cost of capital -in particular short-term capital-- above its international opportunity cost. This presumably had differential effects across firms depending on their ability to obtain long-term financing abroad. Forbes (2003) takes this issue to the data, by analyzing the behavior of investment of publicly listed companies. She shows that during the period that the encaje prevailed, smaller firms faced a higher cost of capital and less investment. She interprets this as a cost of the encaje.

\footnotetext{
${ }^{11}$ This reserve requirement ranged from $25 \%$, for loans shorter that 36 months, to $10 \%$ for loans between 48 and 65 months in maturity. Trade credit was excluded. See Edwards and Cox-Edwards (1991).

${ }^{12}$ One of the reasons behind the collapse was the weakness of corporate sector balance sheets to tolerate a massive exchange rate adjustment, which ultimately contaminated a poorly regulated banking system. We will return to this issue with further detail in section 6 .
} 
Although suggestive, we believe that this result must be interpreted cautiously. Although the encaje was clearly a variable that distinguished the periods analyzed, there are other factors that could also explain the differences in firm behavior across size. One of these were restrictions placed on international bond issuance. During the 1990s, regulations requiring a minimum size and credit rating for international bond issues effectively excluded many smaller firms from the international bond market ${ }^{13}$. These limits were gradually relaxed, so that in 1998 the minimum rating was lowered to BBB-and the minimum size reduced to 5 million dollars.

\section{Differential Effects on Financial Sector}

As mentioned in section 2, an interesting characteristic of the Chilean economy in the 1990s is the direct external indebtedness of corporations, with domestic banks playing a minor role in intermediating international debt. To see whether this is Chilean quirk or a feature common to other emerging economies, we explore whether banks in Chile intermediate a relatively low share of international debt in comparison to other economies at similar levels of development. To do so we look at the behavior of bank and non-bank debt inflows for a sample of capital importing countries during the nineties. For each country we calculate the average ratio of bank inflows over total debt inflows over two periods: 1990-96 and 2000-03. We exclude the period 1997-99, as it is a period of substantial changes in the regulations affecting the Chilean capital account, and also a period of substantial instability in aggregate capital flows. We then regress the ratio of bank inflows to total debt inflows against a broad measure of development, the log of GDP per capita (PPP at the beginning of each period). We also include a dummy for Chile, an interaction of the Chile dummy with a dummy for the second period, and the second period dummy itself.

The results are shown in table 3 . The basic result of column (1) shows that the estimated coefficient on the income variable is positive and significant: banks play a larger role in intermediating capital inflows in high-income economies (which we interpret as countries with more highly developed financial systems). More importantly, the Chilean dummy is negative, significant and sizeable. The share of bank inflows in total debt

\footnotetext{
${ }^{13}$ Corporations required a rating equal or more than sovereign risk and the minimum size of borrowing was set at 50 million dollars
} 
inflows in Chile is $20 \%$ lower than the level predicted by its income level in the period 1990-96. This difference disappears in the latter period, as indicated by the positive and significant coefficient on the interaction between the Chile dummy and the second period dummy. This result is robust to changes in the sample (column 2), using a direct measure of financial development (bank credit over GDP, again at the beginning of each period in column 3) and an alternative measure of capital inflows (columns 4-6).

A possible explanation of this finding is that closely monitored banks found it harder to avoid paying the encaje than corporations, so that the effective cost of foreign credit for banks was higher. If this were the case, the encaje would have had important distributional effects across firms. Small firms (reliant on short term bank credit) would have born the brunt of the encaje, while large firms (able to borrow in international markets or to evade the encaje), would have been relatively unaffected.

An alternative explanation is in the recent development of the Chilean derivatives market. As we mentioned above, Caballero et al. (2004) find that in Australia a large share of foreign debt is intermediated by banks. They also find that banks lend most of these funds in Australian dollars, and use the derivatives market to hedge their positions. Indeed, banks in Australian are the largest holders of net currency derivative positions. This being the case, the development of the Chilean derivatives markets in the last few years is a possible explanation for the increased role of banks in international debt flows.

Finally, changes in capital account regulations after 1998 (discussed in the appendix), in particular those changes pertaining bond issue may also have played a part in switching the mix away from direct international borrowing towards bank intermediated foreign borrowing. Currently, as a result of some combination of market development, the consolidation of a flexible exchange rate regime and further liberalization of bank borrowing, the composition of Chile's private external debt is not significantly different to what would be predicted according to international patterns.

\section{Bank Regulations, International Borrowing and Financial Crises}

We show above that banks in Chile during the 90s intermediated a relatively low share of international debt inflows - with most international borrowing done directly by 
corporations. We also show that in the years after the capital account was fully liberalized and the exchange rate floated, banks have begun playing a significantly larger role in debt inflows. There are two opposing views on the benefits and risks of this increased participation of banks in international capital flows. On the one hand, Caballero et al. (2004) have argued that the larger role that banks in Australia play in international borrowing vis-à-vis Chilean banks, allows the economy greater resilience to external demand shocks by enhancing access to international capital, especially to firms and consumers that do not have direct access to the international capital markets. The Chilean experience in 1982, on the other hand, suggests exactly the opposite: large foreign liabilities on bank balance sheets can become a source of vulnerability. If currency risk is not correctly managed by the banking system, a large devaluation can lead to a financial crisis $^{14}$.

We think that both arguments have a case. The optimality of increased intermediation of capital flows by domestic banks depends crucially on the incentives banks have for correctly managing aggregate risk - in particular exchange rate risk - and the tools available for the banks to manage such risks. Banking regulation and macroeconomic policy both have a direct impact on bank's incentives to hedge against exchange rate uncertainty. The ability to contract foreign debt in the domestic currency, a well developed domestic currency debt market that is both liquid and covers a broad range of maturities, and the development of a derivatives markets are all tools that allow banks to take on foreign debt without necessarily taking on exchange rate risk. ${ }^{15}$ In this section we concentrate on the importance of bank regulation. In the following section we turn our attention to exchange rate policy, and it's effect on debt inflows.

Banking regulation has played a key role in determining the size and nature of capital inflows to Chile. As mentioned above, capital controls in Chile in the early 80s were more stringent than those in mid nineties. Bank regulation, however, was radically different. In what follows of this section, we look at bank regulation in the early 80s, and

\footnotetext{
${ }^{14}$ For recent discussion on the negative affects of international borrowing in the context of a fragile banking system see Soto (2000).

${ }^{15}$ A series of papers, adressing the issue of domestic financial dollarization, have also made this point. This literature emphasizes the interactions between exchange rate regimes and bank regulations in determining the share of domestic bank contracts denominated in foreign currencies. IADB (2005) contains a recent survey.
} 
argue that it played an important part in the large capital inflows, banking mostly, of the period and the resulting financial crisis. ${ }^{16}$

Following a period of state control and financial repression, a series of measures thrust the Chilean financial system into the free-market arena in the second half of the 70s. In May 1974 financieras (finance houses) were authorized to operate, and to freely fix interest rates. Commercial banks, mostly state controlled, still had fixed rates and quantity controls. Then, in April 1975 banks were allowed to freely determine interest rates. During this year, over $86 \%$ of state owned banks were privatized. Hence, by the time of full capital account opening in April 1980, Chilean banks had been operating in a free market system for no more than five years. In Chile domestic financial liberalization happened before international financial opening, but the former was far from well done, as we discuss below.

Initially there was no explicit deposit insurance in Chile, and authorities advocated a market oriented banking system in which depositor monitoring would avoid excessive risk taking by banks. However, In December of 1976, a series of financieras defaulted on their deposits. This led to the intervention of the Banco Osorno, which was at the center of a large business group. The government bailed out $100 \%$ of the deposits of the troubled financieras. In addition, an explicit deposit guarantee of $~ 2500 \mathrm{US}$ per depositor was put in place. A series of authors have argued that the bailout of the financieras led to the belief that all deposits would be guaranteed (see Arellano 1983, Velasco 1991, and De la Cuadra and Valdés-Prieto, 1992). There were also official statements from authorities that reinforced this idea. This belief would explain why, despite repeated problems with banks and financieras in the late 1970s, there never was a substantial run on deposits in Chile (Velasco 1991)

Rules setting prudential constraints on lending and investment portfolios and those forcing timely disclosure of accurate information evolved slowly over the period 1975 to 1982. In addition, the government recognized its limited enforcement capacity, so that many rules (in particular those related to related lending) were poorly enforced. Early legislation (1975) setting a maximum individual holding of bank property at 3\% was

\footnotetext{
${ }^{16}$ For a recent discussion on the development of the Chilean financial market since the 80 s, see Cifuentes et al. (2002).
} 
discarded after extensive abuse. As a result recently privatized banks were purchased by existing and new grupos (conglomerates). It was only after 3 large banks and series of financieras (which together made up $8 \%$ of deposits) went into crisis in late 1981 that limits on related lending were introduced. However, no consideration was made in these limits for firm ownership structure, so that binding limits on related lending were really only introduced in 1982. The result was highly concentrated lending. For example, Arellano (1983) argues that one of the causes of the Fluxa group intervention was the high concentration of assets, mostly to related companies (see also Moulian and Vergara 1979).

Evaluating the health of a bank therefore required information not only on the bank itself, but also on the financial health of the conglomerate. Information available to depositors was also limited by the slow implementation of loan risk classification rules by regulators. Although the SBIF was authorized to classify loans by risk as early as January 1978, it did not issue specific rules for this classification until February 1980 and did not fully enforce classification until 1982.

At the same time as the lack of risk classification mechanisms, and cross ownership made private monitoring extremely costly, the growing belief of full deposit insurance lowered the incentives for this monitoring. Compounding the problem, legislation setting prudential constraints on lending and investment portfolios evolved slowly and in some cases was weakly enforced by a government. The presumption was that private monitoring and legislation classifying managers' actions as fraud (punishable by prison terms) was enough to limit excessive risk taking by banks. As argued by Barandiarán and Hernandez (1999) the government was keen for the financial sector to help reactivate economy, hence "rules on collateral were simple and many loans were not properly secured, rules on nonperforming loans and loss provisions were below international standards, rules for asset classification were only implemented gradually." Capital adequacy ratios existed (5\% of liabilities) but their effectiveness was limited by a weak asset classification system.

Another factor that was indicative of the large distress that was incubating the financial system was the high interest rates, as well as spreads between lending and borrowing rates. At the time of the liberalization real loan rates climbed to more than $60 \%$, which by 1980 had declined to $12 \%$. But as the crisis was emerging, real loan rates increased sharply to $39 \%$ in 1981 and $35 \%$ in 1982, even with a fully open capital account. 
One could think that there could be an overshooting at the early stages of the financial liberalization (De la Cuadra and Valdés-Prieto, 1992). Although it is not easy to rationalize the magnitudes in Chile, more difficult is to argue that this was the case in the early 1980s. Nor one can explain the high rates by a peso problem. ${ }^{17}$ The most likely factor was the rollover of bad loans made by banks, which was due to the expected bailout that banks perceived as financial fragility was growing, a problem that was exacerbated by related lending.

All in all, it is not possible to determine how much of the ensuing credit growth was the result of "excessive" risk taking by banks. What is clear, however, is that the incentives for risky behavior by banks were present and that prudential regulation was weak and unable to avoid this conduct. Legislation had to be modified continuously as regulators became aware of highly concentrated lending patterns and risky loans. This was not a healthy financial system that collapsed because of the large external shocks that hit the economy in the early 80 s: prior to 1983 , the country had already seen two episodes of substantial banking distress.

The flip side of the lending boom were large capital inflows to the banking sector. As we mentioned above, international borrowing financed a substantial share of bank lending in the early 80s. After 1980, banks had open access to international capital markets. With their funding base suddenly expanded, banks intermediated large volumes of foreign debt - all of which was denominated in dollars. By regulation banks were required to "match" the currency composition of their liabilities with their assets, and hence lent sizeable amounts to local firms in dollar-indexed debt. This matching did not mean however, that banks were not exposed to large systemic risks due to currency exposure. It simply meant that the risk was shifted to the corporate balance sheets. Banks traded currency risk for systemic default risk. We return to the evidence on mismatch in section 7.

Independently of whether they were aware of this risk or not, bank regulators had a limited ability to deal with it because of the existing exchange rate system. How could banks set provisions or cap exposure for exchange rate risk if Central Bank authorities (by fixing the exchange rate) were committing to eliminating this risk completely?

\footnotetext{
${ }^{17}$ See Velasco (1991) for further discussion and additional references.
} 
In the end, some combination of excessive idiosyncratic risk (due to bank moral hazard) and systemic risk (due to large exchange rate exposure) precipitated the financial crisis. The interaction of a poor financial regulation and the systemic risk generated by a fixed exchange rate were key determinants of this outcome.

\section{Exchange Rate Regimes and International Borrowing}

An interesting fact in the Chilean experience is that the large inflows of 1996-1997 occurred in the presence of massive reserve accumulation, a commitment to a (relatively) stable exchange rate, and capital controls. As discussed above existing evidence indicated that capital controls did not have a major impact on these inflows. In this section we turn to another aspect of the Chilean policy mix that we argue did play a central role in the Chilean international borrowing experience - the exchange rate regime.

Standard approaches to international capital flows assume risk neutrality across the board, and therefore focus exclusively on uncovered interest parity (or the failure of it) as an explanation for capital movements. However, if borrowers in emerging markets are risk averse, then the decision to borrow from abroad will depend not only on the expected interest rate differential between domestic and foreign loans, but also on the variance of debt service payments in the domestic currency. All else equal, a more volatile nominal exchange rate (or real exchange rate if the relevant variance is of real peso values of debt payments) will make dollar borrowing relatively less attractive to risk adverse local borrowers whose income is denominated in the local currency. The role of the "currency mismatch" implicit in this argument has received extensive attention in the recent literature on the balance-sheet effects of currency mismatches, and their role in recent financial crisis. Firms or consumers, faced with a large depreciation and unhedged dollar-liabilities experience a negative net-worth shock, which leads to lower output, investment or consumption. ${ }^{18}$

All else equal we should expect that firms and consumers take these balance sheet effects into consideration when choosing the level and currency composition of their foreign debt. If currency composition is not a choice, as is indeed the case for most

\footnotetext{
${ }^{18}$ Krugman (1999a,b) presents a stylized version of this effect, while Aghion, Bacchetta, and Banerjee (2001) and Céspedes, Chang, and Velasco (2004) incorporate this mechanism into more fully articulated models.
} 
emerging market economies (see Eichengreen et al 2004), then for a given expected interest rate differential between foreign and domestic debt, the level of foreign debt will be decreasing in the expected variance of the exchange rate.

This implies that countries with credible fixed or managed exchange rates should, all else equal, experience larger debt inflows. Furthermore, even if the fixed exchange rate is not credible, it may still have a positive effect on inflows if agents believe that an exchange rate pre-commitment makes a government bailout in the case of a devaluation more likely or prevents banking regulation from explicitly addressing exchange rate risk. In the previous section we discussed how this might have operated in the banking system in Chile in the early 80s, where regulators had their hands tied when it came to regulating the risks arising from dollar lending. Similar concerns have been expressed for the case of Argentina, where dollarization also extended to domestic debt contracts. Beyond the banking system, the preferential exchange rate agreements put in place after the Chilean crisis in 1982 are one form of such a bailout: dollar indebted firms where allowed to buy discounted dollars with which to pay-off their dollar debts. If indeed firms in Chile in the early 80 s believed that the government would bail them out in event of depreciation, they were ultimately proven right by the events that unfolded after the peg was abandoned.

In this section we want to test this hypothesis empirically so as to determine to what extent the exchange rate regime may have played an important part in Chile's international borrowing experience. However the many policies and external conditions prevailing at the time in Chile make it impossible to separate the effects of the exchange rate regime and capital controls on the evolution of capital inflows. Because of this we estimate the effects of capital controls and the exchange rate regime on capital inflows using cross-country regressions. We examine the period of large capital inflows from 1991 to 1997 to explore the effects of capital controls and the exchange rate regime on the speed of inflows. Our dependent variable is the increase in external debt. For this variable we use two measures: the increase in the external debt to GDP ratio and the rate of growth of external debt.

We estimate regressions for the increase in debt on the exchange rate regime and the extent of capital controls, and other control variables that may affect international borrowing. The other control variables are three: exchange rate volatility, the rate of growth of the economy, and the initial ratio of external debt to GDP. 
We compute the volatility of the exchange rate during the period, as the volatility of the monthly exchange rate, to control for fluctuations in the exchange rate. Perhaps what makes a difference regarding the volume of capital inflows is the actual fluctuation of the exchange rate rather than the declared exchange rate regime. A highly volatile exchange rate may prevent investors from taking advantage of arbitrage opportunities to avoid losses from exchange rate risk. However, from the point of view of expectations of market participants it is essential to understand the logic of the authorities when intervening the foreign exchange market, and hence volatility could exacerbate flows under the presumption that authorities will intervene as a result of fear of floating. For this reason we still think that the declared exchange rate regime is relevant. The impact of exchange rate volatility on capital inflows is different if volatility happens in a fixed or floating exchange rate regime.

Growth is clearly endogenous, and what should affect the increase in borrowing is the growth potential. For this reason, the predicted value of growth for the period 19901995 from cross-country growth regressions, from De Gregorio and Lee (2004), was used as an exogenous variable. This variable should proxy for the potential of the economy and, hence, for the demand for international borrowing.

We also consider the initial level of external debt to GDP. ${ }^{19}$ This variable could have either a positive or negative effect on indebtedness. The negative effect could come from the fact that high initial level of debt may indicate that the economy may be closer to a point where solvency could be questioned, which could slowdown the availability of debt. However, we could observe a positive sign, when a large level of foreign debt may be a signal that the country is less liquidity constraint, and so it has more funds available to borrow.

To proxy for capital controls we use the index constructed by Chinn and Ito (2002). This index is based on four dummy variables. One to indicate whether the country has multiple exchange rates, the second the existence of restrictions on current account transactions, the third is based on restriction on capital accounts transactions and the last one on the requirement of the surrender of export receipts. The global index on capital

\footnotetext{
${ }^{19}$ We could also have controlled for initial GDP, as proposed by Lane (2004), but this is in the growth forecast and also related to the initial level of debt.
} 
controls intensity is the first standardized principal component of the four indices. Chinn and Ito (2002) are interested in the effects of financial integration, and hence their measure takes a higher value the more open the country is to cross-border transactions, and hence this is an index increasing in financial integration. In contrast, we are interested in the extent of capital controls, and for this reason we multiply by -1 the Chinn-Ito index, to have an index increasing in capital controls. Therefore, we would expect that when capital controls are effective, an increase in the index (more controls) should result in a decline of international borrowing and hence the coefficient should be negative. We also used the proxy constructed by Quinn (2003), and the results are basically the same, although in that case we had fewer observations.

To control for the exchange rate regime we use the index constructed by LeviYeyati and Sturzenegger (2002). We consider their de jure and de facto definitions for their three-way classification (fixed, managed and floating). To initiate our investigation we include the intermediate regime together with fixed. Later on, we separate the three regimes.

We construct a cross-section of countries with an initial sample of 80 of middle and high-income countries, but because of data availability we end up reporting regressions for 26 to 57 observations. This will help us also to check the robustness of the results to changes in the sample.

The first set of regressions is presented in table 4, where fixed and managed exchange rate regimes are put together. The dependent variable is the change in the debt to output ratio. Regressions (1) to (4) present the de jure classification, and from (5) to (8) the de facto one. The coefficient on the exchange rate regime appears with a positive sign and is always significant at conventional significance levels. This evidence confirms that countries with fixed or managed exchange rate regimes experienced a larger increase in external debt. The coefficient on the volatility of the exchange rate is always not significantly different from zero.

Regarding capital controls, the coefficient of the proxy for capital controls is only marginally significant, and with the wrong sign, when the exchange rate regime variable is based on the de facto classification and the growth forecast is excluded (regression (6)). The result could be due to correlations between the exchange rate regime and the 
pervasiveness of capital controls. In fact, it is expected that the more controlled is the exchange rate regime the more likely is the prevalence of capital controls. However, the correlation between the de jure classification and the index of capital controls is zero, and with the de facto classification is only 0.25 in our sample, so the insignificance of the capital controls variable does not stem from the correlation of controls with the exchange rate regime.

For the other two variables used in the regressions we found that growth forecast has the expected sign, although it is insignificant in all the specifications. On the other hand, the initial level of debt with respect to GDP is negative, consistent with the idea that the as debt increases borrowing constraints in international financial markets may become more relevant.

As a final check to examine whether the irrelevance of some variables is due to possible correlations with the exchange rate regime, regression (9) excluded the exchange rate regime altogether from the regression. As the table shows, the insignificance of exchange rate volatility, capital controls and the growth forecast remain.

We run the same regressions for the percent change in external debt and the results were similar, although the exchange rate regime was not significant in some of the regressions. The problem may be due to the fact that the fixed exchange rate regime is classified together with the intermediate. For this reason in tables 5 and 6 we separate the three exchange rate regimes using dummy variables. Both tables report the same regressions and the only difference is in the dependent variable. Table 5 presents the results for the change in the external debt to GDP ratio, and table 6 the results for the percent change of external debt.

The results are similar to those of 4 . The volatility of the exchange rate and the growth forecast always result insignificant. Capital controls only appear marginally significant in two regressions of table 6, and again with the wrong sign. On the other hand, initial external debt to GDP is always negative and significant at conventional levels.

The regressions show that external debt grew more in countries with fixed and managed exchange rates than in countries with flexible exchange rates. This is valid for the de jure and the de facto classifications, and for the two alternative measures of the dependent variables as can be seen in both tables. These results also hold for the 
regressions that include all the controls and those that only have the exchange rate regime, and therefore, it holds for the more restricted sample of 26 observations and the enlarged one with 56 observations. The only exception is regression (6) of table 6, where we do not find a significant coefficient for fixed exchange rates, but also inflows are larger in countries with managed exchange rate than floating.

Moreover, an interesting result that appears in almost half of the regressions is that the increase in debt was higher in countries with managed exchange rates than in countries with flexible exchange rates. This can be seen in the regressions that have a larger sample, (4), (5), (9) and (10) in both tables, as well as (6) to (8) of table 6. In the more restricted sample, the largest increase is in countries with fixed exchange rate. Although the results still confirm that the lowest increase in debt was in countries with flexible exchange rates, the results are less definite when comparing fixed versus managed exchange rates.

This last result may be explained by the fact that managed exchange rate regimes may be, in some instances, more prone to investors speculating against the exchange rate regime. As long as managed exchange rates, such as the one in Chile in the 90s, imply a limited defense on the exchange rate, investors may speculate against the authority capabilities to defend the currency, and hence the results should not be a surprise. This could lend support to the bipolar view on exchange rate regimes, namely it is better to have fully fixed or floating exchange rate regimes, and middle grounds are dominated by the extremes.

Several other estimations were done to check robustness. First, as the dependent variable we also used the average balance in the financial account over GDP during 199197, as well as the average change in net foreign assets as reported by Lane and MilesiFerretti (2001). The exchange rate regime never was significant. We interpret this as an indication hat the flow that is actually affected by the exchange rate regime is debt, rather than portfolio flows or FDI. We also made some changes to the sample, excluding highly indebted countries, and countries with less than one thousand dollars of per-capita GDP. These changes reduced the sample between 2 and 4 in the regressions with 26 observations, and up to 10 observations in the enlarged sample. There were no changes in the results with those modifications of the sample. 
Overall, the international evidence reported here shows those countries with fixed and managed exchange rates are more prone to increases in external debt, and capital controls do not play a significant role in reducing debt inflows. The best way to prevent excessive borrowing is to let the exchange rate to fluctuate rather than to use capital controls. More work could be done to check the robustness of our results, but the evidence presented here is already very persuasive.

\section{International Borrowing and Currency Mismatches}

Much recent discussion has emphasized that the currency mismatches that may arise from international borrowing are an important source of international vulnerability. Firms and consumers holding dollar-denominated debt, but whose income is not highly correlated with the exchange rate, see the local currency value of their debt expand relative to their income and assets following depreciation. This deterioration in their balance sheet reduces, or may even reverse, the expansionary effect a depreciation is assumed to have. With this in mind, this section presents evidence on the extent of currency mismatches in Chile in both the banking and corporate sectors.

We start with data on currency mismatches in 1982. Figure 10 shows the mismatch between assets and liabilities denominated in dollars in the banking system. As expected, there were no mismatches in the early eighties, as regulation forced all domestic loans in dollars had to be fully backed by liabilities in dollars ${ }^{20}$. It is clear, therefore, that the currency mismatch that existed in the Chilean economy in 1982 was not on the balance sheets of the banks, but in the corporate sector.

There is no detailed data on currency mismatches in the corporate sector during this period. However some sense of the existing currency imbalances can be obtained by looking at the sectorial composition of the foreign currency lending of the banking system. That there was a currency mismatch problem in the corporate sector is evident in table 7. Considering the first three sectors as tradeable and the rest as non-tradeables, the figures

\footnotetext{
${ }^{20}$ In Chile regulation regarding currency exposure of the banking system is dictated by the Central Bank. The first change occurred with the debt crisis in August 1982, when banks were allowed to have a maximum exposure to foreign currency of $20 \%$ of basic capital (capital plus reserves). Regulation has been basically the same until today. However, in August 1998 the global limit was maintained, but the computation of mismatches distinguished among currencies. The weighting of each currency, which assigns factors of $1,1.5$ and 5, was based on the risk classification of countries of origin.
} 
show that $53 \%$ of total loans in foreign currency went to non-tradeable sectors. We do not have information on the hedging practices of corporates in Chile, but the large devaluation of June 1982 caused the bankruptcy of the banking system, triggered by insolvencies at the corporate level.

Figure 10 shows that by the mid 90s the total dollar value of foreign currency exposure of banks increased. However, as figure 11 shows, the magnitudes are relatively small relative to total assets and therefore do not constitute a major source of vulnerability in the banking system. On the whole, the Chilean banking system of the late $90 \mathrm{~s}$ is not highly dollarized, a marked contrast with the early 80s. In 1981, about $70 \%$ of total liabilities were comprised of dollar deposit and foreign debt. In contrast, in 2003 this was only $24 \%$, and regulation insured that mismatches are within safe limits given banks' levels of capitalization.

As we argue above, a large share of Chilean foreign debt is not intermediated by the banking sector, but directly by firms. The picture painted by the bank data in figures 10 and 11, may therefore provide a partial view of total foreign debt in the economy. In addition, as we mentioned above, it is not dollar-debt that matters for financial vulnerability, but currency mismatches. It is therefore important to not only know how much foreign debt there is, but also who holds the debt; in particular, whether firms whose income is more correlated with the exchange rate are those firms that hold higher foreign liabilities. To do this we turn to firm level data on the currency composition of firm liabilities.

Our data consists of firm-level accounting information for non-financial corporations in Chile for the period 1993 to 2002. In addition, we have data on firm exports and sectors in which the firms operate. Our main source of information is the FECU database of the Superintendencia de Valores y Seguros (SVS). ${ }^{21}$ Data on the currency composition of liabilities and assets is not recorded directly in the FECUS, but is reported in the notes attached to each firm's Annual Financial Statistics. These notes are neither standardized nor available in an electronic format. Because of this, we start with

\footnotetext{
21 The FECU database has standardized accounting data for all firms categorized as Sociedades Anonimas Abiertas. By law these firms must disclose their accounting information using a standardized format (the Ficha Estadistica Codificada y Uniforme FECU). We use non-consolidated data, so that investments in subsidiaries are reported in a separate account and not as a part of the aggregate stock of fixed assets.
} 
the data on foreign currency liabilities assembled by Benavente et al. (2003). ${ }^{22}$ We then input data on foreign currency assets and derivatives collected from each of the notes mentioned above $\mathrm{e}^{23}$. For our estimates, we use a sample restricted to the non-financial firms for which foreign-currency data are available. The size of the sample changes as new firms are incorporated into the SVS database, but it consists of about 150 firms

The distribution of dollar debt is presented in table 8 , where we separate the entire period in two sub-periods. The first was the period from 1993 to 1998 of managed exchange rate and capital controls, and the following, the post-Asian crisis period with flexible exchange rate that goes from 1999 to 2002. The table shows that in both dollar debt is less than $25 \%$ of total liabilities over 1993-1998, and that this share declined slightly in the second sub-period. The table also shows that firms (and/or lenders) take into account the elasticity of their income to the real exchange rate when choosing currency composition of liabilities, as exporters and firms in the tradeable goods sector have a larger share of their liabilities in terms of dollar debt.

In addition, large firms also hold more dollar debt. This has three possible explanations: fixed costs in accessing international capital markets, the size restrictions mentioned in section 4 , and lower costs of a mismatch, since we would expect that large firms suffer less from fluctuations in their accounting net-worth. Finally, firms that hold foreign assets, another proxy for the elasticity of income to the real exchange rate, hold more dollar debt. Therefore, as expected or desired, firms that are less vulnerable to exchange rate fluctuations are also those that hold more dollar debt.

The final panel of table 8 presents simple measures of currency mismatch. Starting with the ratio of total dollar debt to total assets, we then subtract the net currency derivative position of the firm, and then in turn, subtract dollar-indexed assets. Once assets and derivative positions are considered, average currency mismatches for Chilean corporates are below $5 \%$ of total assets in the first period, and close to zero in the second periods.

Cowan et al. (2005) confirm that it is this currency mismatch - or exposure - that makes firms financially vulnerable to a depreciation and not dollar debt. Using firm level data, they fail to find a differential effect of depreciations on firms with higher levels of

\footnotetext{
22 This database is part of a broader effort by the IADB to put together data on firm level currency composition of liabilities. For more details see Galindo et al. (2003).

${ }^{23}$ This dataset is also used in Cowan, Hansen and Herrera (2005).
} 
dollar debt in Chile ${ }^{24}$. In other words, Chilean firms with higher dollar-debt do not invest less than their peso indebted counterparts following depreciation. They argue that this result does not invalidate the balance-sheet mechanism, but that instead it shows the importance of using measures of currency mismatch to determine vulnerability instead of debt measures. Indeed, as we discussed above, the fact that Chilean corporates match the currency composition of their liabilities with that of their incomes, means that negative balance sheet effects are offset by positive competitiveness gains, so that dollar debt is a poor measure of mismatch.

The fact that even before floating the exchange rate and the elimination of capital controls currency mismatches in Chilean corporates where minor, lends support to the idea that firms had a prudent attitude toward exchange rate changes even before it was allowed to float. This suggests, in turn, that the exchange rate band did not provide full implicit insurance to those holding unhedged foreign debt and that a sharp exchange rate adjustment before 1999 would not have resulted in serious financial problems for the corporate sector. In addition, more instruments to hedge currency exposure have become available to Chilean firms since the peso started to float as the FX derivative market has deepened significantly (De Gregorio and Tokman, 2004).

\section{The US-Chile Free Trade Agreement}

Chile signed a Free Trade Agreement with the US in 2003. This agreement involved some commitments in terms of capital flows, and a relevant issue is whether Chile could re-impose capital controls, in particular on inflows. The chapter on financial services considers the free mobility of capital with no provisions. However, annex 10-C to the chapter on investment establishes some margins to the application of capital controls by establishing the legal actions that investors can take against Chilean authorities in case of disputes regarding controls on capital movements. ${ }^{25}$

In terms of capital controls on outflows, Chile has not used them since the crisis of the 80s, and even when pressures on the peso were at its maximum in 1998 they were not used. But, annex 10-C says that Chile will not incur in liabilities for costs arising from the

\footnotetext{
${ }^{24}$ These are in line with previous results by Bleakley and Cowan (2002) for 5 Latin American countries, and more recent results for 8 East Asian economies by Luengnaruemitchai (2004).
} 
imposition of restrictions on outflows as long as they are not applied for more than a year, and the restrictions do not "substantially impede transfers." Therefore, restrictive and focalized measures for up to a year are still possible. But the agreement explicitly excludes transfers from FDI and external debt payments as agreed in original terms of the loan from the one-year restriction to submit claims.

The most relevant issue is restrictions on capital inflows, in which case investors may take legal action when they are impeded to invest in Chile. However, there are constraints on these actions. Chile should not be subject to claims from losses incurred within one year from the date restrictions are imposed. The first year can be applied along the same principles of outflows. The treaty also establishes that a claim can be submitted only after one year has elapsed from the loss incurred by the investor, which in fact would result in two years after the application of the restriction. In addition, the loss that can be claimed is limited only to interest losses, and no other costs, such as loss of profits or business. There is no class action, and therefore all investors should submit claims independently. Therefore, Chile could still impose, although for a shorter period, capital controls on inflows, although with less degrees of freedom than in the 90s.

However, the main limit to the application of capital controls in Chile was their workings itself. In order to encourage domestic investors to invest abroad during the application of the encaje, most investment abroad was guaranteed the possibility to return without having to pay the encaje. This amount is large and current estimates indicate that about 27 billion of dollars could return free of encaje. Therefore, these investments have plenty of arbitrage opportunities in case Chile re-imposes the reserve requirement.

Therefore, Chile is more limited to apply capital controls than in the past. In particular the ability to impose controls for a year is more relevant for outflows than inflows. The historical experience suggests that transitory controls are more important to prevent outflows during a speculative attack, rather than on inflows, which require a longer-term application. The limitations of Chile to impose capital controls is the combined result of the FTA with the US, but more important by the same regulations and guarantees granted during the period of capital inflows. Regardless the feasibility of application of controls, the relevant question is their desirability. In the case of Chile, the

\footnotetext{
${ }^{25}$ This annex is reproduced in Appendix 2 of this paper.
} 
financial system is strong, there is a credible flexible exchange rate regime--with minimal reasons for fear of floating (De Gregorio and Tokman, 2004)--, and inflation is low. Therefore, the arguments used to impose capital controls in the 1990s are much less important today, and, in addition, as argued in this paper, it is not clear that they even were effective.

\section{Why Chile Did Not Have a Sudden-Stop?}

Following the Asian-Russian crisis Chile experienced a sharp reversal in net capital flows, which has led many observers to use it as example of sudden-stops in capital inflows. Total net inflows fell from over 6 billion dollars in 1997 to 0.5 billion dollars per year during 1999-2000. As seen in Table 9, this drop is comparable, and in some cases larger, than that experienced by other emerging economies that underwent capital account reversals during the 90s. These events raise the question of Chilean external vulnerability. Why, despite relatively low levels of foreign debt, low currency mismatches and relatively high levels of (allegedly) safe foreign direct investment was Chile vulnerable to a capital account reversal of this magnitude?

In this section we argue that the negative shock to the supply of international capital played a minor role in the collapse of net capital flows to Chile. Indeed, the size of the international liquidity shock, the causes of the adjustment and the mechanism through which the different shocks were amplified set Chile apart from other emerging economies that experienced sudden stops in the late 90s. We argue that in Chile an initial large current account deficit, a sharp decline in the terms of trade, a contractionary monetary policy and the defense of the currency were the factors that triggered the adjustment in capital flows. In fact, Chile's situation is better understood as a current account reversal combined with a sudden-start in capital outflows by domestic residents than a sudden stop in the inflows by non-residents.

The main lesson from this experience is (once again!) that consistent macroeconomic policy matters, irrespective of the structure of gross foreign liabilities. As we documented above, despite controls on capital inflows Chile had grown increasingly integrated into international capital markets (a point also made recently by Lane and Milessi-Ferreti 2004). As a consequence of this integration - and in much the same way as 
in Europe in the early 90s - inconsistent macro policy lead to large net capital movements despite the high share of "safe" FDI in Chilean international liabilities. An additional lesson is that recent attention to "third" generation currency crisis is justified in terms of what happened in Asia, but not in Chile. Indeed, as financial integration increases previous "varieties" of crisis may become more likely in emerging market economies.

\section{Sudden Stop or Sudden-Start?}

In the later part of the Asian-Russian crisis and its immediate aftermath, the period 1998-99, net capital inflows to Chile dropped by close to $8 \%$ of GDP. At the same time, the external financing conditions for Chile deteriorated, pushing up the cost of international borrowing. Figure 12 shows the spread between the returns on Chilean corporate and public bonds and the rates on US treasury bills. Between 1997 and 1999, the spread on Chilean corporate bonds doubled. Data for public bonds suggests a similar pattern for sovereign spreads. The timing of the rising spread on Chilean bonds coincides with large hikes in the spread on bonds from other emerging market economies, as measured by the spread aggregate EMBI bond index. The rise of corporate and sovereign spreads in 1998, and their failure to drop to initial levels even after the current account deficit was closed in 2000 are evidence that, along with many other emerging markets, Chile experienced a negative shock to the supply of international savings.

Despite similar pattern on spreads and the net capital account, Chile is different from other countries that experienced sudden stops in the late 90s. The first is in the level

of country risk measured by the bond spreads. Even at its peak, risk premia on Chilean corporate bonds was lower than the average emerging market risk before the Asian crisis (see figure 12). Moreover, there are episodes where the corporate bond spread has been even higher, such as the second semester of 2002, and the domestic consequences were much smaller than during the Asian-Russian crisis, providing additional evidence that the problem was not mainly with foreign lending, but with other factors.

Second, Chile ranks low in many of the variables that Calvo et al. (2004) identify as determinants of sudden stops, a point made originally by Calvo and Talvi (2005). According to Calvo et al. (2004), sudden stops are usually the result of an international credit shock that is amplified by the interaction between currency mismatches and a real depreciation. Faced with restricted access to international credit, currencies are forced to 
depreciate so as to close the gap between the current and capital accounts, with the size of depreciation depending on the relative size of the tradeable sector. For those countries with large unhedged foreign currency liabilities, this depreciation causes large negative balance sheet effects that amplify the initial shock, and lead to further reductions in output and expenditure. In Chile, dollar liabilities in the banking sector are small, and the corporate sector is relatively well hedged as shown in section 6. Mismatches in the public sector are also small - even before including copper revenues in the picture (Ministerio de Hacienda, 2003).

The behavior of gross capital flows sheds light on what was happening with capital flows in Chile at the time of the sudden-stop. Figure 13 shows the path of gross inflows and outflows for Chile over 1996-02. Following the Asian-Russian crisis, total gross inflows into Chile actually increased, while non-FDI gross inflows remained virtually unchanged. Gross outflows, on the other hand, increased substantially, peaking at over 10 billion dollars during 1999. There is no clear evidence that access to foreign capital was curtailed, as gross outflows explain the bulk of the collapse in net inflows.

The relative importance of gross inflows and outflows in the Chilean episode is atypical within sudden-stop episodes in emerging economies. The last column of table 10 shows the share of the net capital reversal during the sudden stop episodes in emerging markets that is explained by changes in gross inflows. In the average sudden stop episode experienced by emerging economies $98 \%$ of the net capital flow reversal can be explained by changes in gross inflows, i.e. by stops or reversals in the flow of funds from nonresidents. Since inflows actually increased in Chile in 1998-99, the share explained by gross inflows is negative. Chile experienced more of a sudden-start in outflows than a sudden stop in inflows in this period!

The behavior of two groups of institutional investors explains a large share of the total gross outflows from Chile in this period: pension fund management companies (AFPs) and banks. ${ }^{26}$ Pension funds increased the share of foreign assets in their portfolio from close to $1 \%$ in 1997 to above $10 \%$ in 1999 . This corresponds to capital outflows to the order of 5\% of GDP. As this rising share of assets coincided with a widening of the legal investment limits on foreign asset holdings for AFPs it is hard to determine whether the

\footnotetext{
${ }^{26}$ See Caballero (2002) and Caballero et al. (2004) for a more detailed discussion of this point.
} 
outflow was driven by the macroeconomic events of this period or it was simply an easing of a binding regulatory constraint.

The behavior of banks is more interesting. Banks contributed to capital outflows by substantially increasing the share of foreign assets in their portfolios. Starting from less that $1 \%$ in 1997, the ratio of foreign assets to total assets peaked at over 6\% in 1999 (figure 14). This corresponds to an outflow of close to 5\% of GDP. As shown in the figure, banks also increased their net dollar asset position over this period, taking on more exchange rate risk. This suggests that these outflows were not solely the response of banks looking to hedge rising dollar deposits. Interestingly, the share of foreign assets in total assets declined after the peso was floated in 1999, but much before country risk returned to its pre-crisis levels. Both the rising net asset position and the timing of the foreign asset spike suggest that banks took on a net dollar position to take advantage of arbitrage opportunities that arose prior to the currency being floated in 1999. In effect, Chilean residents were betting against an exchange rate policy that tried to minimize depreciations, while in fact the large negative external shocks pushed the equilibrium real exchange rate upwards. The position against the peso that was taken by banks and fear of floating on the part of the authorities induced the Central Bank to severely tighten liquidity in the inter-bank market in $1998 .^{27}$

Finally, the timing of events also sets Chile apart from countries that experienced sudden stops. The Chilean peso came under severe pressure in January 1998. This lead to an immediate monetary tightening which successfully fended off a depreciation (during 1998 the peso only depreciated 8\%). The international liquidity shock, evident in the evolution of spreads (figure 12), only began in July-August 1998. Therefore, in terms of timing, the original shock come from the exchange rate and monetary policy response.

\section{Exchange rate policy}

Following the Asian crisis in 1997 Chile's terms of trade deteriorated significantly pushing up the equilibrium real exchange rate. Concerned with the effects of a nominal depreciation on inflation, and the loss of credibility that this would entail if the fixed annual

\footnotetext{
${ }^{27}$ De Gregorio and Tokman (2004) argue that there were no reasons for fear of floating since balance sheet effects were not enough to cause serious financial distress and the pass-through from exchange rate to prices was relatively low to fear an outburst of inflation.
} 
inflation target was not met, the Chilean Central bank set out to minimize the nominal devaluation and reign in nominal demand. To do so it implemented a contractionary monetary policy (figure 15). ${ }^{28}$ In part the monetary contraction was also aimed at closing a large current account deficit. Since mid 1997 the current account deficit had been increasing, reaching a peak of about $8 \%$ of GDP in 1998, which authorities believed was unsustainable (figure 16). Simultaneously the Central Bank intervened in the foreign exchange market- selling close to 2 billion dollars in reserves in 1998 alone.

The combination of a negative terms of trade shock, rising international interest rates and contractionary domestic monetary policy led to a substantial slow down in economic activity. Output growth fell from over 6\% in 1997 and 1996 to 3\% in 1998, and then it declined by $1 \%$ in 1999 . Simultaneously, unemployment rose from $5 \%$ to over $7 \%$ in 1998 (figure 17). As in the Obstfeld (1996) currency crisis model ("second" generation), the rising output cost of the currency defense pushed up depreciation expectations, which in turn made the defense of the currency increasingly costly. This resulted in capital outflows of agents (banks in particular!) wishing to cash in on arbitrage opportunities from the gradual depreciations during 1998 and 1999. As we argued before, a gradually appreciating exchange rate induces inflows. This experience reinforces that argument by showing that gradual depreciations promote outflows. Capital outflows by the banks, the portfolio recomposition by the AFPs and a contractionary monetary policy all combined to generate a severe credit crunch, depressing consumption and investment and leading to a large reduction in the current account.

Overall, the Chilean experience was the result of a reversal in the current account, induced primarily by a very tight monetary policy and domestic liquidity squeeze, a sharp decline in terms of trade, and a strong defense of the peso. The pressures on the peso were caused by international turmoil and a change in the equilibrium exchange rate of Chile, after the deterioration of external conditions. In contrast, the international liquidity shock that caused a sudden-stop in many emerging markets played a secondary role.

\footnotetext{
${ }^{28}$ These are monthly figures. Looking at daily figures shows more clearly the extent of the domestic liquidity squeeze. In January 1998 went up to $100 \%$ in one day and in July and September it reached almost $60 \%$. The figure is drawn up to July 2001, since until then the policy interest rates, and most market rates, were set in temrs of the UF (a Chilean unit of account indexed to the price level).
} 


\section{Conclusions}

What then are the lessons from the Chilean experience with international borrowing?

The first is that domestic financial regulations, in particular regarding the financial system, play a crucial role in determining the level and composition of capital inflows. Despite a more restrictive encaje in the early 1980s than in the 1990s, and regulations limiting bank balance sheet currency mismatches, poor regulation of the banking system in Chile led to large inflows of debt, a substantial part of which was on-lent to the nontradeable sector. The resulting corporate mismatch and additional problems such as asset concentration due to related lending and expectations of banks-bailout contributed to the deep financial crisis that Chile experienced in 1982.

Second, and perhaps the most important lesson, the exchange rate regime plays and important role in determining debt inflows, currency mismatches and financial vulnerabilities. Fixed exchange rates, such as the one Chile had between 1979 and 1982 provide an implicit guarantee to borrowers and lenders alike. As long as the regime holds, borrowers and lenders are protected from exchange rate volatility. If, on the other hand, the currency depreciates, agents believe that they are entitled to transfers and bailouts from the government, leading to excessive risk taking ex-ante. Ex-post they have usually been proven right, as in the case of preferential exchange rate deals in Chile, or more recently, through the pesification in Argentina. A fixed exchange rate regime also makes it very complicated to introduce prudential regulation for currency mismatches into banking legislation. How can you ask banks to insure against an event you are guaranteeing will never happen? But the real problem lies beyond banks, and therefore policies must be consistent with incentives for corporates to avoid excessive mismatches and banks for monitoring it, which requires careful rules to regulate related lending and implicit massive guarantees on the banking system.

More generally, rigidities in the exchange rate system may amplify shocks to the supply of international capital. In "good" periods, a rigid exchange rate regime provides implicit insurance to borrowers, reducing the risks of interest rate arbitration. The risk of postponing an adjustment, i.e. allowing the exchange rate to appreciate during a surge of capital inflows, is an incentive for further capital to flow in while assets still remain undervalued, putting additional pressures on an appreciation of the currency. In bad 
periods, delaying depreciations amplifies external shocks by piling higher depreciation expectations onto an already higher risk premia.

Finally, the encaje at best played a small role in the size and nature of debt inflows to Chile. Most studies, show that it did have an effect on the maturity composition of inflows, but that the magnitude of this effect is small. On the other hand, there is little evidence that is had a significant effect on total inflows or on the real exchange rate. Moreover, the proper functioning of restrictions, which attempted to deter flows in and encourage flows out, has its drawbacks. In the Chilean case there is an important stock of investment that left the country when the encaje was in place, and in order to encourage the outflow, they were insured to be able to return without the imposition of controls, which limits the scope for restrictive measures.

In addition, this paper raises a series of additional issues regarding the Chilean experience. The first is the role of banks in intermediating capital inflows. Up to 1999, banks in Chile intermediated very little international debt. Post 1999, this seems to be changing. One explanation for this is the encaje. An alternative explanation is the recent development of the derivatives market, which allows banks to borrow abroad without burdening themselves or their borrowers with currency risk. For the development of this market in turn, the internationalization of pension funds and the volatility that the flexible exchange rate regime has brought, have been very important.

The second is currency mismatches. Using firm level data for the late 90 s we show that currency exposure in Chilean corporates was low, and that it fell after 1999. Bank level data from 1982, on the other hand, suggest that mismatches in the corporate sector prior to the crisis in 1983 were sizeable. Again, the commitment to a fixed exchange rate coupled with weak regulation induces mismatches. While the most recent experience shows that despite some rigidity in the exchange rate, there was no implicit insurance and not bad loans due to related lending that could have induced excessive currency mismatch and financial sector fragility.

Third, Chile experienced a substantial slow down in capital inflows in the late 90s. We argue, that the exogenous international credit shock played a minor role in this reversal. Most of the action came from a sudden start of outflows not from a sudden stop of inflows. Therefore, the Chilean case is better described with second-generation currency crisis 
models than with more recent models that center on balance sheet effects. In Chile, a negative terms of trade shock and an initially large current account deficit were amplified by a sharp tightening of monetary policy and an inconsistent exchange rate policy. The current account reversal that took place was not accompanied by a sudden stop of inflows in the capital account, but by a sudden start of outflows. Consistent with the fact that a gradually appreciating currency encourages inflows, a gradually depreciating currency promoted outflows. 


\section{References}

Aghion, P., P. Bacchetta and A. Banerjee (2001). "Currency Crises and Monetary Policy in an Economy with Credit Constraints." European Economic Review 45(7): 1121-50.

Arellano, J.P. (1983), "De la Liberalización a la Intervención: El Mercado de Capitales en Chile 1974-83", Colección Estudios CIEPLAN, N.11.

Barandiarán, E. and L. Hernández (1999), "Origins and Resolution of a Banking Crisis: Chile 1982-86”, Documentos de Trabajo N.57, Banco Central de Chile.

Benavente, J. M., C. Johnson and F. Moránde (2003). "Debt Composition and Balance Sheet Effects of Exchange Rate Depreciations: a Firm-Level Analysis for Chile." Emerging Markets Review 4(2003) 397 - 416.

Bleakley, H. and K. Cowan (2002) "Dollar Debt and Devaluations: Much Ado About Nothing?" Federal Reserve Bank of Boston, Working Paper \#02-5, December.

Caballero (2002), “Coping With Chile's External Vulnerability: A Financial Problem”, mimeo MIT.

Caballero, R., K. Cowan, and J. Kearns (2004), "Fear of Sudden Stops: lessons from Australia and Chile," Research Discussion Paper 2004-03, Reserve Bank of Australia.

Calvo, G., A. Izquierdo and L.F. Mejia (2004). "On the Empirics of Sudden Stops: the Relevance of Balance-Sheet". Research Working Paper \# 509, Inter-American Development Bank.

Calvo, G. and Reinhart, C. (2002), "Fear of Floating," Quarterly Journal of Economics 177: 379-408.

Calvo, G. and Talvi, E. (2005), "Sudden Stop, Financial Factors and Economic Collapse in Latin America: Learning from Argen and Chile,", NBER Working Paper 11153.

Céspedes, L. F., R. Chang and A. Velasco (2004). "Balance Sheets and Exchange Rate Policy." The American Economic Review 94(4): 1183-93

Chang, R. and A. Velasco (1999). "Illiquidity and Crises in Emerging Markets: Theory and Policy." NBER Macroeconomics Annual 1999.

Chinn, M. and H. Ito (2002), "Capital Account Liberalization, Institutions and Financial Development: Cross Country Evidence,” NBER Working Paper No. 8967. 
Cifuentes, R., J. Desormeaux and C. Gónzalez (2002), "Capital Markets in Chile: From Financial Repression to Financial Deepening," Documento de Política Económica No. 4, Central Bank of Chile, forthcoming, BIS Papers.

Cowan, K., Hansen, E. and Herrera, L.O. (2005). "Currency Mismatches, BalanceSheet Effects and Hedging in Chilean Non-Financial Corporations". Inter-American Development Bank, Working Paper \#521.

De Gregorio, J., and J. W. Lee (2004), "Growth and Adjustment in East Asia and Latin America," forthcoming, Economía.

De Gregorio, J. and A. Tokman (2004), "Overcoming Fear of Floating: Exchange Rate Policies in Chile," Central Bank of Chile, Working Paper No. 302, December.

De Gregorio, J., S. Edwards, and R. Valdés (2000), "Controls on Capital Inflows: Do They Work?," Journal of Development Economics, Vol. 63, Issue 1, pp. 59-83.

De la Cuadra, S. and S. Valdés-Prieto (1992), "Myths and Facts about Financial Liberalization in Chile: 1974-1983," in P. Brock (ed.), If Texas were Chile, ICPS, San Fancisco.

Diamond, D. W. and P. H. Dybvig (1983). "Bank Runs, Deposit Insurance, and Liquidity." Journal of Political Economy 91(3): 401-19.

Eichengreen, B., Hausmann, R. and Panizza, U.(2004). “The Pain of Original Sin” in Other People's Money: Debt Denomination and Financial Instability in Emerging Market Economies Barry Eichengreen and Ricardo Hausmann editors.

Edwards, S. (1999) "How Effective are Capital Controls," Journal of Economic Perspectives, 13 (4): 65-84.

Edwards, S. and A. Cox-Edwards (1991), Monetarism and Liberalization: The Chilean Experiment, Second Edition with a New Afterword, University of Chicago Press, Chicago.

Forbes, K. (2003), "One Cost of the Chilean Capital Controls: Increased Financial Constraints for Smaller Traded Firms,” NBER Working Paper No. 9777.

Galindo, A., Panizza, U. and Schiantarelli, F. (2003). "Debt composition and balance sheet effects of currency depreciation: a summary of the micro evidence," Emerging Markets Review, Elsevier, vol. 4(4), pages 330-339, 12

Gallego F., L. Hernández and K. Schmidt-Hebbel (1999), "Capital Controls in Chile: Effective, Efficient?," Central Bank of Chile Working Paper Series, No 59.

Herrera, L.O and R. Valdés (2004), "Dedollarization, Indexation and Nominalization: The Chilean Experience.” Economic and Social Study Series, IADB. 
IADB (2005). "Unlocking Credit: The Quest for Deep and Stable Bank Lending". At http://www.iadb.org/res/ipes/2005/index.cfm.

Jadresic. E., S. Lehman, A. Rojas, J. Selaive and A. Naudon (2003), "Análisis del Balance Financiero Externo de Chile," Documento de Política Económica No. 7, Central Bank of Chile.

Krugman, P. (1999a). "Analytical Afterthoughts on the Asian Crisis." At http://web.mit.edu/krugman/www.

Krugman, P. (1999b). "Balance Sheets, the Transfer Problem, and Financial Crises." International Tax and Public Finance 6(4): 459-72.

Lane, P. (2004), "Empirical Perspectives on Long-Term External Debt," Topics in Macroeconomics, Volume 4, Issue 1.

Lane, P. And G. Milesi-Ferretti (2001), "The External Wealth of Nations: Measures of Foreign Assets and Liabilities for Industrial and Developing Countries," Journal of International Economics, 55, 263-294, December.

Lane, P. and G.M Milesi-Ferretti (2004), "Financial Globalization and the Exchange Rate", mimeo IMF.

Levy-Yeyati, E. and F. Sturzenegger (2002), "Classifying Exchange Rate Regimes: Deeds vs. Words", forthcoming, European Economic Review.

Luengnaruemitchai, P. (2004). "The Asian Crises and the Mystery of the Missing Balance Sheet Effect". Mimeo, Department of Economics, University of California at Berkeley.

Moulian, T. and P. Vergara (1979), "Coyuntura Economica y Reacciones Sociales: Las fases de la Política Económica en Chile 1973-78”, Apuntes CIEPLAN N. 22.

Nadal De-Simone, F., and P. Sorsa (1999), "Capital Account Restrictions in Chile in the 1990s," mimeo, IMF.

Obstfeld (1996), "Models of Currency Crisis With Self Fulfilling Features", European Economic Review 40" 1037-48.

Quinn, D. (2003), "Capital Account Liberalization and Financial Globalization, 18901999: A Synoptic View," International Journal of Finance and Economics, 8,3: 189204.

Radelet, S. and J. D. Sachs (1998). "The East Asian Financial Crisis: Diagnosis, Remedies, Prospects". Brookings Papers on Economic Activity 0(1): 1-74. 
Soto, M. (2000), "Capital Flows and Growth in Developing Countries: Recent Empirical Evidence," Technical Paper No. 160, Development Centre, OECD.

Soto, M., and S. Valdés-Prieto (1996), “¿Es el Control Selectivo de Capitales Efectivo en Chile? Su Efecto Sobre el Tipo de Cambio Real," Cuadernos de Economía 33 (98): 77 104.

Velasco, A. (1991), "Liberalization, Crisis, Intervention: the Chilean Financial System 1975-1985," in V. Surandararajan and T. Baliño (eds.), Banking Crisis: Causes and Issues, IMF, Washington. 


\section{APPENDIX 1: Main capital controls and exchange regulations, 1990-2004}

\section{Unremunerated Reserve Requirement}

\section{June}

A 20\% reserve requirement is applied to foreign loans. The reserve is for a minimum period of 90 days and maximum 1 year. Pre-payments (merchandise must be shipped within six months) and charges are exempt.

\section{January}

The $20 \%$ reserve requirement on foreign loans is extended to commercial banks' sight and term deposits in foreign currency.

June

The reserve required is increased from $20 \%$ to $30 \%$. The reserve period for Chapter XIV loans is uniformly set at 1 year and, in the case of banks, the days are counted as consecutive days instead of bank working days. A liquidity credit line in dollars is established to constitute the reserve.

\section{July}

Secondary ADRs (American Depository Receipts) and investments not destined to the formation or increase of a local company's social capital are now subject to a reserve requirement in order to broaden the productive capacity of goods or services, excluding straightforward financial flows.

\section{March}

Foreign loans entirely destined to the prepayment of foreign loans which were duly authorized and registered with the Central Bank are excluded from the reserve requirement while the weighted average terms of the new loan and the remaining original loan remain similar.

\section{September}

The reserve required on firms' foreign loans contracted by way of bond issues is eliminated when the financing thus obtained is to finance investment abroad or to refinance liabilities of the firm's agents or affiliates abroad.

\section{October}

A reserve is established for portfolio investment made according to the stipulations of Chapter XIV of the Compendium of Foreign Exchange Regulations (CNCI) even when this investment is to constitute or increase the capital of firms already established in the country if it is not made to increase productive capacity of goods and services nor to contribute to the firms' productive operation. The reserve requirement is still excepted in the case of investment made to acquire first issue shares on the grounds of an ADR convention.

\section{December}

Loans, capital contributions and investment for amounts less than US\$200,000 are exempt from the reserve requirements, but the same agent must not exceed US\$500,000 in the past twelve months. This measure is eliminated during 1997.

\section{June}

The reserve rate on foreign loans, capital contributions and investment is lowered from $30 \%$ to $10 \%$ for the first year. Short-term banking system liabilities (credit lines and the public's cash deposits) continue subject to the $30 \%$ reserve but two-thirds of the reserve will be remunerated.

\section{August}

The reserve requirement is lifted from capital inflows destined to ADR arbitrage transactions in the secondary market. 


\section{September}

The exchange reserve is reduced to zero on all capital inflows. At the same time, the reserve rate on foreign currency sight and term deposits and loans is reduced to make the reserve cost in foreign currency the same as in local currency.

\section{April}

The $0 \%$ reserve requirement on incoming capital is eliminated.

\section{$\underline{\text { Loans, investment and capital contributions from abroad }}$}

\section{April}

The minimum period that capital contributions entering Chile under the stipulations of Chapter XIV of the $\mathrm{CNCI}$ must remain in the country is reduced from three years to one year.

\section{May}

The minimum period of one year that investments and capital contributions must remain in the country, as stipulated in Chapter XIV of the CNCI, is eliminated.

\section{April}

The capital account is completely freed by eliminating all remaining restrictions, but keeping the requirement that financial-type exchange transactions must be channeled through the formal exchange market and the Central Bank informed of those exchange operations that it decides.

Consequently, prior authorization is no longer needed for capital inflows associated with foreign loans, investment and capital contributions, the same as for capital outflows associated with capital returns, dividends and other benefits relating to capital contributions and investments and prepayments of foreign loans. The obligation of selling and/or buying foreign currency on the formal exchange market is also eliminated as well as the restrictions on the currency in which foreign loans may be granted or taken.

\section{January}

Financing obtained from foreign loans, investments and capital contributions may be freely used abroad including the capitalization of any outstanding debt abroad.

2003-2004

More simple requirements are set regarding information on all exchange matters regulated by the CNCI.

\section{Bond issues abroad}

\section{May}

Residents in Chile are authorized to obtain foreign loans by placing bonds abroad. Bond issuers must have an A rating from the Risk Classifying Commission of the Pension Fund Administrators.

\section{April}

Solvency levels required for banks and non-banking companies are lowered to BBB and BBB+, respectively. Moreover, non-banking companies' minimum amount requirement is lowered from US\$ 50 MM to US\$25 MM, stays at US\$ 50 MM for banks, and the need for the Central Bank's express authorization is eliminated.

\section{November}

Funding obtained from bond issues abroad no longer has to be brought back to Chile. It can be held in a bank account abroad and used to pay back foreign loans or imports that have been approved and registered with the Central Bank or it can be invested in foreign instruments abroad.

\section{April}


Minimum amount requirements for bond issues abroad are eliminated and the required international risk classification of the issuing company is lowered. The weighted average term of subordinated bond issues made by banking companies is lowered from ten to five years to come into line with the new Bank Act.

The issue of bonds abroad denominated in Chilean pesos or in UF is authorized, but these cannot be traded nor offered in Chile and must be disbursable and payable in foreign currency.

\section{June}

Funding generated by bond issues, under the stipulations of Chapter XIV, can be put to wider uses thereby allowing for the issue of Bonds for Infrastructure.

\section{April}

Non-banking debtors can issue bonds at maturities of less than four years and the risk classification required for longer-term bonds is lowered.

\section{May}

Bonds denominated in Chilean pesos or in UF can now be accepted as liabilities payable in foreign currency. Interest paid on these bonds is thus subject to the same tax rate as traditional bonds denominated in foreign currency $(4 \%)$.

\section{April}

Capital inflows obtained from bond issues are no longer restricted by requirements of prior authorization. Also the requirements of minimum risk classification of the issuing company and minimum weighted term of the bond issues are eliminated.

\section{$\underline{\text { ADR Issues }}$}

\section{April}

ADR trading is introduced by which residents abroad can acquire shares in Chilean corporations. Companies must meet requirements with respect to the minimum amount of the issue and risk classification of the firm, differentiating between banking and non-banking companies.

\section{April}

The minimum amount requirement for issuing ADRs is eliminated and the minimum level of international risk classification is lowered.

\section{August}

To simplify capital movements, the reserve requirement on incoming capital for ADR arbitrage operations in the secondary market is eliminated.

\section{April}

Chapter XXVI of the CNCI is broadened to allow securities to be issued in stock exchanges abroad by way of instruments other than the ADRs on the New York Stock Exchange. It also allows company development funds and real estate investment funds to issue quotas abroad.

\section{April}

Restrictions on ADR issues are eliminated. 


\section{Investment abroad}

\section{April}

To widen investment opportunities, individuals' own foreign currency or that they have acquired on the informal exchange market ${ }^{29}$ can now be invested abroad, the Central Bank being duly informed.

\section{April}

Regulation on Chilean residents' investment abroad is changed, mainly in that:

a) prior authorization is no longer required.

b) investment permitted abroad of foreign currency acquired through the formal exchange market is widened

to include granting loans and buying physical assets.

c) remittances must be made through the formal exchange market with the due Central Bank notification.

\section{June}

The investment options abroad for foreign currency not acquired on the formal exchange market are now the same as those authorized for foreign currency acquired on the formal exchange market.

\section{November}

Chapter XII of the CNCI is modified to contain the regulation on foreign currency remittances or availability of funding for amounts over US\$10,000 or the equivalent in other currencies.

\section{April}

All remaining restrictions are eliminated but transactions must still be carried out through the formal exchange market and informed to the Central Bank.

\section{$\underline{\text { Exchange Regulations on Institutional Investors }}$}

\section{January}

Pension Fund Administrators (AFPs) are allowed to invest a maximum of $1.5 \%$ of the total value of the fund in securities approved by the Risk Classifying Commission. This limit was gradually increased until, in January 1999, it reached $16 \%$ and the limit on investment in variable-income instruments was $10 \%$. At the same time, the minimum risk classification of the investment instruments was also gradually lowered.

\section{November}

Insurance companies are authorized to invest abroad in financial investments (10\% of their resources in the case of life insurers and $15 \%$ in the case of general insurers) and in nonresidential urban property (up to $3 \%$ ). Mutual Funds are also allowed to invest abroad (up to $30 \%$ of their resources).

\section{October}

Mutual Funds are authorized to invest abroad using foreign currency obtained in the formal exchange market and the $30 \%$ limit is increased to $100 \%$ of their total assets.

\section{February}

Insurance companies' limit on financial investment abroad is increased from $15 \%$ to $20 \%$ in the case of general insurers and from $10 \%$ to $15 \%$ in the case of life insurers.

\section{May}

\footnotetext{
${ }^{29}$ The law distinguishes between "formal" and "informal" foreign exchange market. The formal market is constituted by banks and the rest is the informal sector. The main difference has been only the information requirements.
} 
The limit on Pension Fund Administrators' investment abroad is raised to 25\% and in 2004 it is raised again to $30 \%$. 


\title{
APPENDIX 2: Annex 10-C of the FTA between Chile and the US.
}

\author{
Special Dispute Settlement Provisions
}

\section{Chile}

1. Where a claimant submits a claim alleging that Chile has breached an obligation under Section A, other than Article 10.3, that arises from its imposition of restrictive measures with regard to payments and transfers, Section B shall apply except as modified below:

(a) A claimant may submit any such claim only after one year has elapsed since the events giving rise to the claim;

(b) If the claim is submitted under Article 10.15(1)(b), the claimant may, on behalf of the enterprise, only seek damages with respect to the shares of the enterprise for which the claimant has a beneficial interest;

(c) Loss or damages arising from restrictive measures on capital inflows shall be limited to the reduction in value of the transfers and shall exclude loss of profits or business and any similar consequential or incidental damages;

(d) Paragraph 1(a) shall not apply to claims that arise from restrictions on:

(i) transfers of proceeds of foreign direct investment by investors of the United States, excluding external debt financing covered in subparagraph (d)(ii), and excluding investments designed with the purpose of gaining direct or indirect access to the financial market; or

(ii) payments pursuant to a loan or bond issued in a foreign market, including inter- and intracompany debt financing between affiliated enterprises made exclusively for the conduct, operation, management, or expansion of such affiliated enterprises, provided that these payments are made in accordance with the maturity date agreed on in the loan or bond agreement;

(e) Excluding restrictive measures referred to in paragraph 1(d), Chile shall incur no liability, and shall not be subject to claims, for damages arising from its imposition of restrictive measures with regard to payments and transfers that were incurred within one year from the date on which the restrictions were imposed, provided that such restrictive measures do not substantially impede transfers;

(f) A restrictive measure of Chile with regard to payments and transfers that is consistent with this Annex shall be deemed not to contravene Article 10.2 provided that, as required under existing Chilean law, it does not discriminate among investors that enter into transactions of the same nature; and

(g) Claims arising from Chile's imposition of restrictive measures with regard to payments and transfers shall not be subject to Article 10.24 unless Chile consents. 
2. The United States may not request the establishment of an arbitral panel under Chapter Twenty-Two (Dispute Settlement) relating to Chile's imposition of restrictive measures with regard to payments and transfers until one year has elapsed since the events giving rise to the dispute.

3. Restrictive measures on payments and transfers related to claims under this Annex shall otherwise be subject to applicable domestic law. 
Table 1: International Investment Position

(millions US\$)

\begin{tabular}{|c|c|c|c|c|c|c|c|c|c|c|}
\hline & & & 1980 & 1985 & 1990 & 1995 & 1999 & 2000 & 2001 & 2002 \\
\hline \multicolumn{3}{|c|}{$\begin{array}{l}\text { Net International Inves. Position (A-B) } \\
\text { (\%GDP) }\end{array}$} & $\begin{array}{c}-7,402 \\
25.1\end{array}$ & $\begin{array}{c}-16,447 \\
90.3\end{array}$ & $\begin{array}{c}-14,988 \\
44.7\end{array}$ & $\begin{array}{c}-23,471 \\
32.6\end{array}$ & $\begin{array}{c}-28,729 \\
39.4\end{array}$ & $\begin{array}{c}-29,314 \\
39.0\end{array}$ & $\begin{array}{c}-29,510 \\
43.1\end{array}$ & $\begin{array}{c}-27,981 \\
41.5\end{array}$ \\
\hline \multirow[t]{5}{*}{ A. } & Asset & & 9,080 & 8,264 & 15,898 & 28,517 & 51,502 & 52,569 & 53,137 & 55,490 \\
\hline & 1. & Foreign Direct Investment & 56 & 103 & 137 & 2,460 & 9,000 & 11,154 & 11,905 & 12,389 \\
\hline & 2. & Portfolio Investment & 0 & 0 & 0 & 52 & 11,402 & 9,876 & 10,662 & 12,988 \\
\hline & 3. & Other Investment (debt) & 4,587 & 4,954 & 8,687 & 10,782 & 16,154 & 16,429 & 16,169 & 14,762 \\
\hline & 4. & International Reserves & 4,436 & 3,206 & 7,074 & 15,224 & 14,946 & 15,110 & 14,400 & 15,351 \\
\hline \multirow[t]{4}{*}{ B. } & Liabili & & 16,482 & 24,711 & $\mathbf{3 0 , 8 8 7}$ & 51,989 & 80,231 & 81,883 & 82,647 & 83,471 \\
\hline & 1. & Foreign Direct Investment & 3,982 & 3,527 & 10,539 & 23,656 & 43,498 & 45,418 & 45,082 & 43,861 \\
\hline & 2. & Portfolio Investment & 107 & 232 & 598 & 6,167 & 10,611 & 9,187 & 10,302 & 11,079 \\
\hline & 3. & Other Investment (debt) & 12,393 & 20,952 & 19,750 & 22,165 & 26,122 & 27,278 & 27,263 & 28,531 \\
\hline \multicolumn{11}{|c|}{ Memorandum Item* } \\
\hline & & External Debt & 12,697 & 21,656 & 20,655 & 25,505 & 34,758 & 37,177 & 38,538 & 40,956 \\
\hline
\end{tabular}

* In the international investment position statistics external debt is mostly included in "other investment", but also in other items, as described in the text . 
Table 2: Short-Term External Debt

\begin{tabular}{|c|c|c|c|c|c|c|}
\hline & \multicolumn{2}{|c|}{ Narrow Definition } & \multicolumn{2}{|c|}{ New Definition } & \multicolumn{2}{|c|}{ Debt Maturing within a Year } \\
\hline & (million US\$) & $(\%$ total debt) & (million US\$) & (\% total debt) & (million US\$) & $(\%$ total debt $)$ \\
\hline & (1) & (2) & (3) & (4) & (5) & (6) \\
\hline 1991 & 2199 & 11.3 & 4346 & 22.3 & 5658 & 29.0 \\
\hline 1992 & 3475 & 16.3 & 5841 & 27.3 & 7239 & 33.9 \\
\hline 1993 & 3487 & 15.9 & 5769 & 26.3 & 7353 & 33.5 \\
\hline 1994 & 3865 & 15.6 & 6859 & 27.7 & 8541 & 34.5 \\
\hline 1995 & 3431 & 13.5 & 6891 & 27.0 & 8636 & 33.9 \\
\hline 1996 & 2635 & 10.0 & 7045 & 26.8 & 8862 & 33.7 \\
\hline 1997 & 1287 & 4.4 & 5522 & 19.0 & 7829 & 27.0 \\
\hline 1998 & 1610 & 4.9 & 5130 & 15.7 & 7672 & 23.5 \\
\hline 1999 & 1171 & 3.4 & 4317 & 12.4 & 7145 & 20.6 \\
\hline 2000 & 2531 & 6.8 & 6172 & 16.6 & 10236 & 27.5 \\
\hline 2001 & 2051 & 5.3 & 5290 & 13.7 & 9944 & 25.8 \\
\hline 2002 & 2324 & 5.7 & 5823 & 14.2 & 11591 & 28.3 \\
\hline
\end{tabular}

Source: Central Bank of Chile. 
Table 3: The Role of Banks in Capital Inflows. Is Chile Atypical?

\begin{tabular}{|c|c|c|c|c|c|c|c|c|c|c|c|c|}
\hline \multirow[b]{3}{*}{ Independent variables } & \multicolumn{12}{|c|}{ Dependent Variable: } \\
\hline & \multicolumn{6}{|c|}{ Bank Inflows / Total Debt Inflows } & \multicolumn{6}{|c|}{ Bank Inflows / Total non-fdi Inflows } \\
\hline & (1) & & (2) & & (3) & & (4) & & (5) & & (6) & \\
\hline $\begin{array}{l}\log (\text { gdp per capita PPP) } \\
\text { beginning of period }\end{array}$ & $\begin{array}{c}0.152 \\
(0.016)\end{array}$ & $* * *$ & $\begin{array}{c}0.161 \\
(0.013)\end{array}$ & $* * *$ & & & $\begin{array}{c}0.142 \\
(0.016)\end{array}$ & $* * *$ & $\begin{array}{c}0.145 \\
(0.013)\end{array}$ & $* * *$ & & \\
\hline $\mathrm{I}($ year $>2000)$ & $\begin{array}{c}0.006 \\
(0.038)\end{array}$ & & $\begin{array}{c}0.034 \\
(0.038)\end{array}$ & & $\begin{array}{l}-0.003 \\
(0.051)\end{array}$ & & $\begin{array}{l}-0.003 \\
(0.038)\end{array}$ & & $\begin{array}{c}0.012 \\
(0.036)\end{array}$ & & $\begin{array}{l}-0.013 \\
(0.051)\end{array}$ & \\
\hline Chile dummy & $\begin{array}{l}-0.218 \\
(0.027)\end{array}$ & $* * *$ & $\begin{array}{l}-0.229 \\
(0.024)\end{array}$ & $* * *$ & $\begin{array}{l}-0.242 \\
(0.033)\end{array}$ & $* * *$ & $\begin{array}{l}-0.212 \\
(0.027)\end{array}$ & $* * *$ & $\begin{array}{l}-0.219 \\
(0.024)\end{array}$ & $* * *$ & $\begin{array}{l}-0.238 \\
(0.033)\end{array}$ & $* * *$ \\
\hline $\begin{array}{l}\text { Chile dummy } \\
\text { x I(year }>2000)\end{array}$ & $\begin{array}{c}0.222 \\
(0.039)\end{array}$ & $* * *$ & $\begin{array}{c}0.189 \\
(0.037)\end{array}$ & $* * *$ & $\begin{array}{c}0.256 \\
(0.053)\end{array}$ & $* * *$ & $\begin{array}{c}0.281 \\
(0.039)\end{array}$ & $* * *$ & $\begin{array}{c}0.264 \\
(0.035)\end{array}$ & $* * *$ & $\begin{array}{c}0.315 \\
(0.053)\end{array}$ & $* * *$ \\
\hline $\begin{array}{l}\text { Bank Credit over GDP } \\
\text { beginning of period }\end{array}$ & & & & & $\begin{array}{c}0.004 \\
(0.001)\end{array}$ & $* * *$ & & & & & $\begin{array}{c}0.004 \\
(0.001)\end{array}$ & $* * *$ \\
\hline \multicolumn{13}{|l|}{ Regression Statistics } \\
\hline $\begin{array}{l}\text { Observations } \\
\text { R-squared }\end{array}$ & $\begin{array}{l}149 \\
0.35\end{array}$ & & $\begin{array}{l}198 \\
0.34\end{array}$ & & $\begin{array}{l}106 \\
0.23\end{array}$ & & $\begin{array}{l}149 \\
0.32\end{array}$ & & $\begin{array}{l}198 \\
0.31\end{array}$ & & $\begin{array}{l}106 \\
0.21\end{array}$ & \\
\hline Sample & $\begin{array}{l}\text { Net Capital } \\
\text { Importers }\end{array}$ & & All & & $\begin{array}{l}\text { Net Capital } \\
\text { Importers }\end{array}$ & & $\begin{array}{l}\text { Net Capital } \\
\text { Importers }\end{array}$ & & & & $\begin{array}{l}\text { Net Capital } \\
\text { Importers }\end{array}$ & \\
\hline
\end{tabular}


Table 4 : Regression Results

Dependent Variable: Change in the Debt to GDP ratio (1991-97)

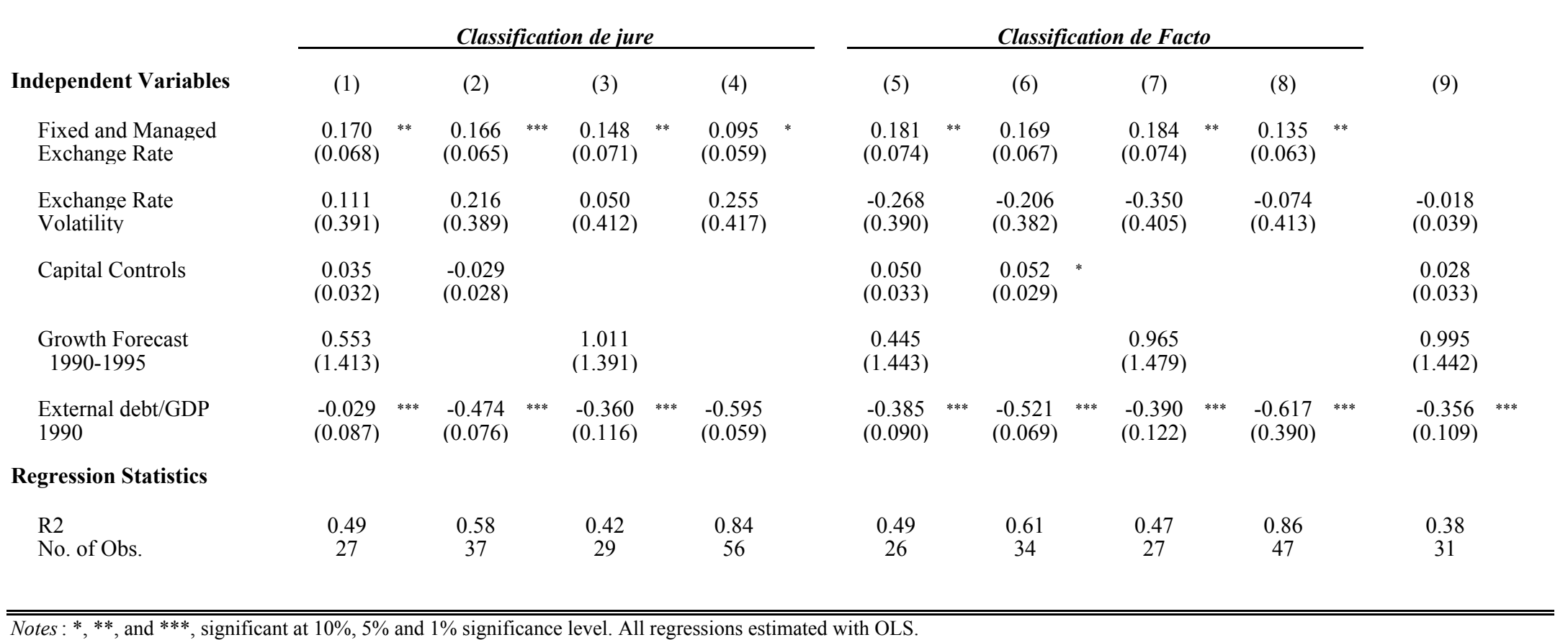

Notes: ${ }^{*}, * *$ and ${ }^{* * *}$, significant at $10 \%, 5 \%$ and $1 \%$ significance level. All regressions estimated with OLS. 
Table 5: Regression Results

Dependent Variable: Change in Debt to GDP Ratio (1991-97)

\begin{tabular}{|c|c|c|c|c|c|c|c|c|c|c|c|c|c|c|c|c|c|c|c|c|}
\hline \multirow[b]{2}{*}{ Independent Variables } & \multicolumn{10}{|c|}{ Classification de Jure } & \multicolumn{10}{|c|}{ Classification de Facto } \\
\hline & (1) & & $(2)$ & & (3) & & (4) & & $(5)$ & & $(6)$ & & (7) & & $(8)$ & & (9) & & $(10)$ & \\
\hline $\begin{array}{l}\text { Fixed } \\
\text { Exchange Rate }\end{array}$ & $\begin{array}{c}0.268 \\
(0.099)\end{array}$ & $* * *$ & $\begin{array}{c}0.249 \\
(0.064)\end{array}$ & $* * *$ & $\begin{array}{c}0.171 \\
(0.103)\end{array}$ & * & $\begin{array}{c}0.274 \\
(0.042)\end{array}$ & $* * *$ & $\begin{array}{c}0.274 \\
(0.042)\end{array}$ & $* * *$ & $\begin{array}{c}0.215 \\
(0.145)\end{array}$ & & $\begin{array}{c}0.327 \\
(0.078)\end{array}$ & $* * *$ & $\begin{array}{c}0.162 \\
(0.143)\end{array}$ & & $\begin{array}{c}0.287 \\
(0.059)\end{array}$ & $* * *$ & $\begin{array}{c}0.287 \\
(0.058)\end{array}$ & *** \\
\hline $\begin{array}{l}\text { Managed } \\
\text { Exchange Rate }\end{array}$ & $\begin{array}{c}0.08 \\
(0.086)\end{array}$ & & $\begin{array}{c}0.158 \\
(0.076)\end{array}$ & ${ }^{* *}$ & $\begin{array}{c}0.091 \\
(0.099)\end{array}$ & & $\begin{array}{c}0.239 \\
(0.066)\end{array}$ & $* * *$ & $\begin{array}{c}0.242 \\
(0.065)\end{array}$ & $* * *$ & $\begin{array}{c}0.184 \\
(0.102)\end{array}$ & * & $\begin{array}{c}0.242 \\
(0.082)\end{array}$ & $* * *$ & $\begin{array}{c}0.177 \\
(0.106)\end{array}$ & * & $\begin{array}{c}0.323 \\
(0.059)\end{array}$ & $* * *$ & $\begin{array}{c}0.317 \\
(0.055)\end{array}$ & $* * *$ \\
\hline $\begin{array}{l}\text { Floating } \\
\text { Exchange Rate }\end{array}$ & $\begin{array}{l}-0.013 \\
(0.080)\end{array}$ & & $\begin{array}{c}0.05 \\
(0.071)\end{array}$ & & $\begin{array}{l}-0.018 \\
(0.093)\end{array}$ & & $\begin{array}{c}0.17 \\
(0.060)\end{array}$ & $* * *$ & $\begin{array}{c}0.181 \\
(0.057)\end{array}$ & $* * *$ & $\begin{array}{c}0.011 \\
(0.096)\end{array}$ & & $\begin{array}{c}0.108 \\
(0.070)\end{array}$ & & $\begin{array}{l}-0.011 \\
(0.100)\end{array}$ & & $\begin{array}{c}0.169 \\
(0.057)\end{array}$ & $* * *$ & $\begin{array}{c}0.169 \\
(0.057)\end{array}$ & *** \\
\hline $\begin{array}{l}\text { Exchange rate } \\
\text { Volatility }\end{array}$ & $\begin{array}{c}0.21 \\
(0.361)\end{array}$ & & $\begin{array}{c}0.242 \\
(0.387)\end{array}$ & & $\begin{array}{c}0.071 \\
(0.414)\end{array}$ & & $\begin{array}{c}0.264 \\
(0.420)\end{array}$ & & & & $\begin{array}{l}-0.232 \\
(0.419)\end{array}$ & & $\begin{array}{l}-0.116 \\
(0.395)\end{array}$ & & $\begin{array}{l}-0.366 \\
(0.427)\end{array}$ & & $\begin{array}{l}-0.128 \\
(0.430)\end{array}$ & & & \\
\hline Capital Controls & $\begin{array}{c}0.499 \\
(0.029)\end{array}$ & * & $\begin{array}{c}0.034 \\
(0.028)\end{array}$ & & & & & & & & $\begin{array}{c}0.053 \\
(0.350)\end{array}$ & & $\begin{array}{c}0.059 \\
(0.030)\end{array}$ & $*$ & & & & & & \\
\hline $\begin{array}{l}\text { Growth Forecast } \\
1990-1995\end{array}$ & $\begin{array}{l}-0.423 \\
(1.364)\end{array}$ & & & & $\begin{array}{c}0.832 \\
(1.408)\end{array}$ & & & & & & $\begin{array}{c}-0.36 \\
(0.128)\end{array}$ & $* * *$ & & & $\begin{array}{c}1.023 \\
(1.563)\end{array}$ & & & & & \\
\hline $\begin{array}{l}\text { External Debt/GDP } \\
1990\end{array}$ & $\begin{array}{l}-0.358 \\
(0.100)\end{array}$ & $* * *$ & $\begin{array}{l}-0.473 \\
(0.075)\end{array}$ & *** & $\begin{array}{l}-0.363 \\
(0.116)\end{array}$ & ${ }^{* * *}$ & $\begin{array}{l}-0.594 \\
(0.037)\end{array}$ & $* * *$ & $\begin{array}{l}-0.594 \\
(0.037)\end{array}$ & $* * *$ & & & $\begin{array}{l}-0.512 \\
(0.080)\end{array}$ & $* * *$ & $\begin{array}{l}-0.384 \\
(0.130)\end{array}$ & *** & $\begin{array}{c}-0.615 \\
(0.039)\end{array}$ & $* * *$ & $\begin{array}{c}-0.615 \\
(0.039)\end{array}$ & $* * *$ \\
\hline Regression Statistics & & & & & & & & & & & & & & & & & & & & \\
\hline $\begin{array}{l}\mathrm{R} 2 \\
\text { No. of Obs }\end{array}$ & $\begin{array}{c}0.59 \\
27\end{array}$ & & $\begin{array}{c}0.60 \\
37\end{array}$ & & $\begin{array}{c}0.44 \\
29\end{array}$ & & $\begin{array}{c}0.84 \\
56\end{array}$ & & $\begin{array}{c}0.85 \\
56\end{array}$ & & $\begin{array}{c}0.50 \\
26\end{array}$ & & $\begin{array}{c}0.62 \\
34\end{array}$ & & $\begin{array}{c}0.47 \\
27\end{array}$ & & $\begin{array}{c}0.86 \\
47\end{array}$ & & $\begin{array}{c}0.87 \\
47\end{array}$ & \\
\hline
\end{tabular}


Table 6 : Regression Results

Dependent Variable: Percent Change in External Debt (1991-97)

\section{Classification de Jure}

\section{Independent Variables}

Fixed

Exchange Rate

Managed

Exchange Rate

Floating

Exchange Rate

Exchange rate

Volatility

Capital Controls

Growth Forecast

1990-1995

External Debt/GDP

1990

\begin{abstract}
(2)
\end{abstract}
R2

No. Of obs

$\begin{array}{ccc}0.34 & 0.23 & 0.29 \\ 27 & 37 & 29\end{array}$

\section{Classification de Facto}

\begin{tabular}{|c|c|c|c|c|c|c|c|c|c|c|c|c|c|c|c|c|c|c|c|}
\hline (1) & & (2) & & (3) & & (4) & & (5) & & (6) & & (7) & & (8) & & (9) & & (10) & \\
\hline $\begin{array}{c}1.31 \\
(0.958)\end{array}$ & $* * *$ & $\begin{array}{c}1.058 \\
(0.244)\end{array}$ & $* * *$ & $\begin{array}{c}1.128 \\
(0.343)\end{array}$ & $* * *$ & $\begin{array}{c}0.985 \\
(0.257)\end{array}$ & $* * *$ & $\begin{array}{c}0.988 \\
(0.255)\end{array}$ & $* * *$ & $\begin{array}{c}0.724 \\
(0.516)\end{array}$ & & $\begin{array}{c}1.034 \\
(0.284)\end{array}$ & $* * *$ & $\begin{array}{c}0.87 \\
(0.474)\end{array}$ & $*$ & $\begin{array}{c}0.927 \\
(0.348)\end{array}$ & $* * *$ & $\begin{array}{c}0.927 \\
(0.344)\end{array}$ & $* * *$ \\
\hline $\begin{array}{c}0.955 \\
(0.340)\end{array}$ & $* * *$ & $\begin{array}{c}0.909 \\
(0.290)\end{array}$ & $* * *$ & $\begin{array}{c}0.925 \\
(0.332)\end{array}$ & $* * *$ & $\begin{array}{c}1.133 \\
(0.369)\end{array}$ & $* * *$ & $\begin{array}{c}1.17 \\
(0.349)\end{array}$ & $* * *$ & $\begin{array}{c}1.193 \\
(0.365)\end{array}$ & $* * *$ & $\begin{array}{c}1.377 \\
(0.300)\end{array}$ & $* * *$ & $\begin{array}{c}1.242 \\
(0.350)\end{array}$ & $* * *$ & $\begin{array}{c}1.407 \\
(0.349)\end{array}$ & $* * *$ & $\begin{array}{c}1.404 \\
(0.326)\end{array}$ & $* * *$ \\
\hline $\begin{array}{c}0.63 \\
(0.318)\end{array}$ & $*$ & $\begin{array}{c}0.594 \\
(0.270)\end{array}$ & ** & $\begin{array}{c}0.605 \\
(0.310)\end{array}$ & $*$ & $\begin{array}{c}0.858 \\
(0.405)\end{array}$ & ** & $\begin{array}{c}0.867 \\
(0.400)\end{array}$ & $* *$ & $\begin{array}{c}0.746 \\
(0.342)\end{array}$ & ** & $\begin{array}{c}0.938 \\
(0.254)\end{array}$ & $* * *$ & $\begin{array}{c}0.757 \\
(0.330)\end{array}$ & $* *$ & $\begin{array}{c}0.711 \\
(0.340)\end{array}$ & ** & $\begin{array}{c}0.711 \\
(0.336)\end{array}$ & $* *$ \\
\hline $\begin{array}{c}0.752 \\
(1.433)\end{array}$ & & $\begin{array}{c}0.867 \\
(1.466)\end{array}$ & & $\begin{array}{c}0.777 \\
(1.382)\end{array}$ & & $\begin{array}{c}0.882 \\
(2.588)\end{array}$ & & & & $\begin{array}{l}-0.889 \\
(1.493)\end{array}$ & & $\begin{array}{l}-0.569 \\
(1.443)\end{array}$ & & $\begin{array}{l}-0.625 \\
(1.416)\end{array}$ & & $\begin{array}{c}-0.06 \\
(2.553)\end{array}$ & & & \\
\hline $\begin{array}{l}-0.062 \\
(0.118)\end{array}$ & & $\begin{array}{l}-0.056 \\
(0.106)\end{array}$ & & & & & & & & $\begin{array}{l}-0.101 \\
(0.126)\end{array}$ & & $\begin{array}{l}-0.037 \\
(0.111)\end{array}$ & & & & & & & \\
\hline $\begin{array}{c}1.744 \\
(5.417)\end{array}$ & & & & $\begin{array}{c}3.677 \\
(1.382)\end{array}$ & & & & & & $\begin{array}{c}5.623 \\
(5.547)\end{array}$ & & & & $\begin{array}{c}4.471 \\
(5.174)\end{array}$ & & & & & \\
\hline $\begin{array}{l}-0.759 \\
(0.399)\end{array}$ & $*$ & $\begin{array}{l}-0.683 \\
(0.286)\end{array}$ & ** & $\begin{array}{l}-0.747 \\
(0.389)\end{array}$ & $*$ & $\begin{array}{l}-0.532 \\
(0.230)\end{array}$ & $* *$ & $\begin{array}{c}-0.532 \\
(0.229)\end{array}$ & ** & $\begin{array}{l}-0.735 \\
(0.452)\end{array}$ & & $\begin{array}{c}-0.898 \\
(0.294)\end{array}$ & $* * *$ & $\begin{array}{l}-0.818^{*} \\
(0.429)\end{array}$ & * & $\begin{array}{l}-0.502 \\
(0.232)\end{array}$ & ** & $\begin{array}{l}-0.502 \\
(0.229)\end{array}$ & $* *$ \\
\hline
\end{tabular}


Table 7: Financial System Lending by Sector in 1981 (millions US\$)

\begin{tabular}{lccc}
\hline & Chilean Currency & & Foreign Currency \\
\cline { 2 - 2 } Agriculture & 2667 & \\
Mining & 292 & 647 \\
Industry & 2421 & 165 \\
Construction & 2262 & 1839 \\
Commerce & 3995 & 908 \\
Transportation \& Telecomm. & 641 & 1427 \\
Financial Services & 4744 & 174 \\
Non Financial Services & 1487 & \\
& & \\
\hline \hline Source: Arellano (1983) & \multicolumn{2}{c}{ n.a. } \\
\hline
\end{tabular}

Table 8: Distribution of Dollar Debt 1993-2002

\begin{tabular}{|c|c|c|}
\hline & $1993-98$ & $1999-02$ \\
\hline \multicolumn{3}{|l|}{ Dollar Debt (\% Total Liabilities) } \\
\hline Full Sample & 23.6 & 20.5 \\
\hline Non Tradeable Sectors & 13.9 & 12.8 \\
\hline Tradeable Sectors & 34.3 & 29.2 \\
\hline No Exporters ( $X<10 \%$ sales) & 19.4 & 15.5 \\
\hline Exporters $(X>10 \%$ sales $)$ & 47.7 & 42.4 \\
\hline Small Firms (assets $<$ median) & 12.2 & 8.8 \\
\hline Big Firms (assets > median) & 35.0 & 32.1 \\
\hline No Dollar Assets (DA $<5 \%$ assets) & 17.7 & 12.9 \\
\hline Dollar Assets (DA $>5 \%$ assets) & 51.6 & 45.8 \\
\hline \multicolumn{3}{|l|}{ Currency Mismatch (\% Total Assets) } \\
\hline Dollar Debt & 8.8 & 8.3 \\
\hline Dollar Debt Net of Derivative Position & 8.5 & 7.0 \\
\hline Dollar Debt Net of Derivative Position and Dollar Assets & 3.1 & 0.0 \\
\hline
\end{tabular}

Source: Author's calculations based on SVS data. 
Table 9 : Sudden Stops in Emerging Economies

\begin{tabular}{lcc}
\hline & $\begin{array}{c}\Delta \text { net inflows } \\
(\% \text { GDP })\end{array}$ & $\begin{array}{c}\text { \% explained } \\
\text { by inflows }\end{array}$ \\
\cline { 2 - 3 } Argentina 95 & -6.0 & 64.0 \\
Argentina 01 & -15.1 & 92.1 \\
Colombia 98 & -6.9 & 95.6 \\
Ecuador 99 & -48.3 & 84.8 \\
Mexico 95 & -10.5 & 91.5 \\
Peru 97 & -8.8 & 94.3 \\
Indonesia 98 & -9.5 & 102.7 \\
Korea 98 & -6.1 & 177.2 \\
Phillipines 97 & -18.5 & 6.8 \\
Thailand 97 & -19.8 & 100.3 \\
Turkey 94 & -7.3 & 147.7 \\
Turkey 98 & -11.4 & 103.8 \\
Turkey 01 & -11.7 & 106.5 \\
Average (no Chile) & & \\
Chile 82 & -13.8 & 97.5 \\
Chile 98 & & \\
\hline \hline
\end{tabular}

Source: authors' construction based on IFS data.

Note: Sudden stop episodes are from Calvo et al. (2004). $\Delta$ net inflows correpond to the difference between the maximum value of net inflows in $[t-3, t]$ and the minimum value in $[t, t+3]$, where $t$ is the year of the sudden stop. $\Delta$ net inflows are scaled by $t-1$ GDP 


\section{Figure 1: Chile's External Debt by Maturity}

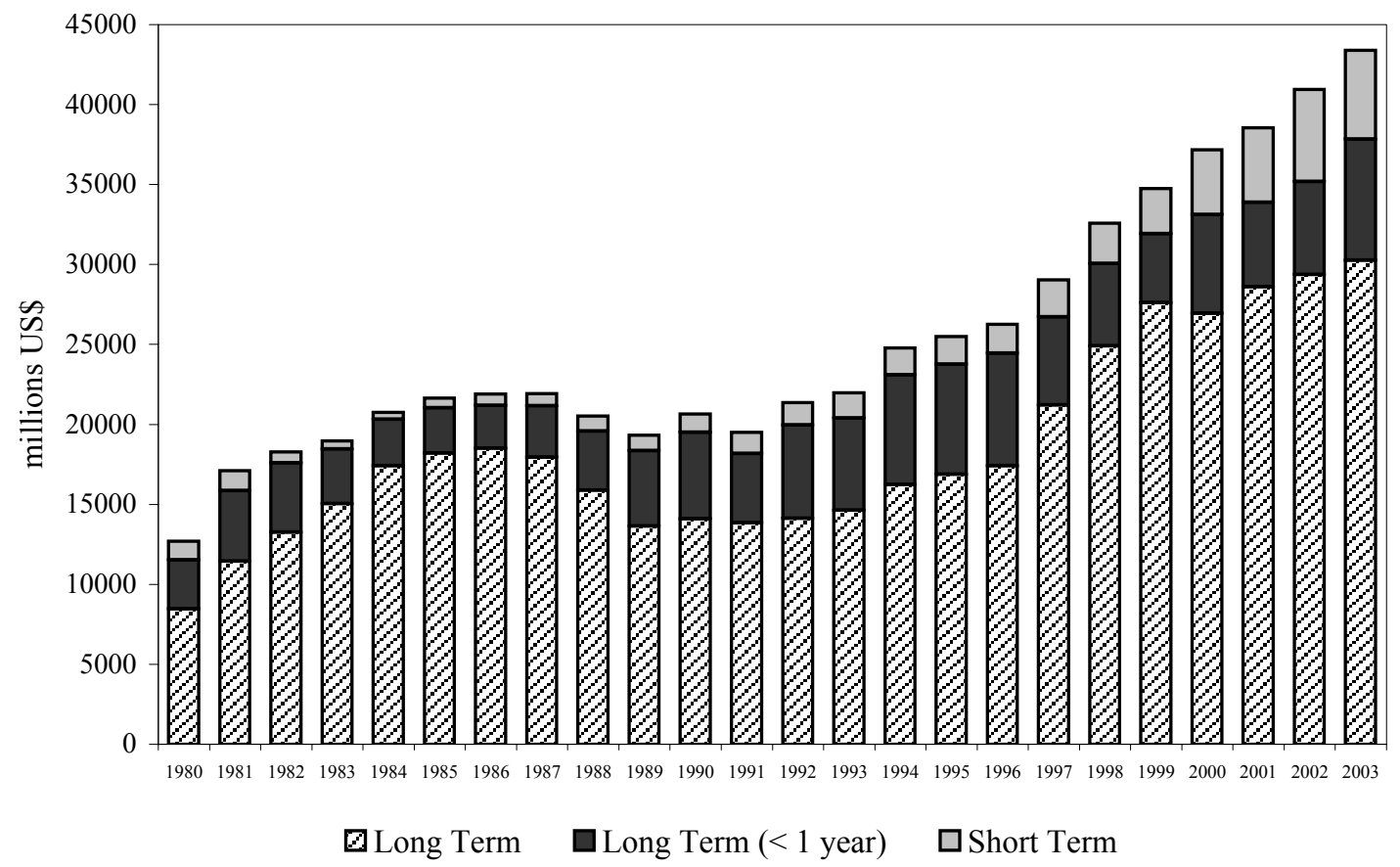

Figure 2: Chile's External Debt

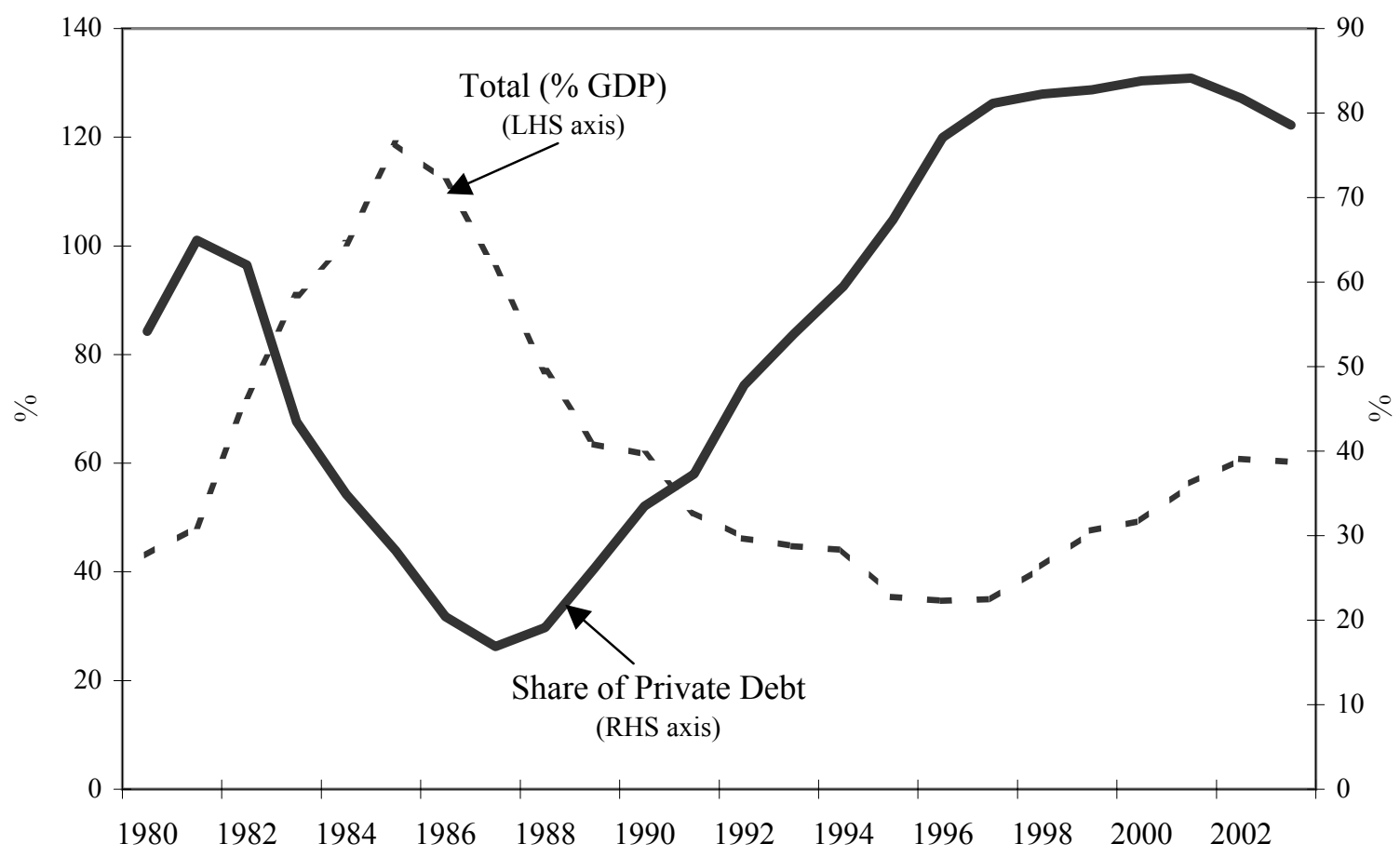

Source : Central Bank of Chile 


\section{Figure 3: Financial and Non-Financial Private External Debt}

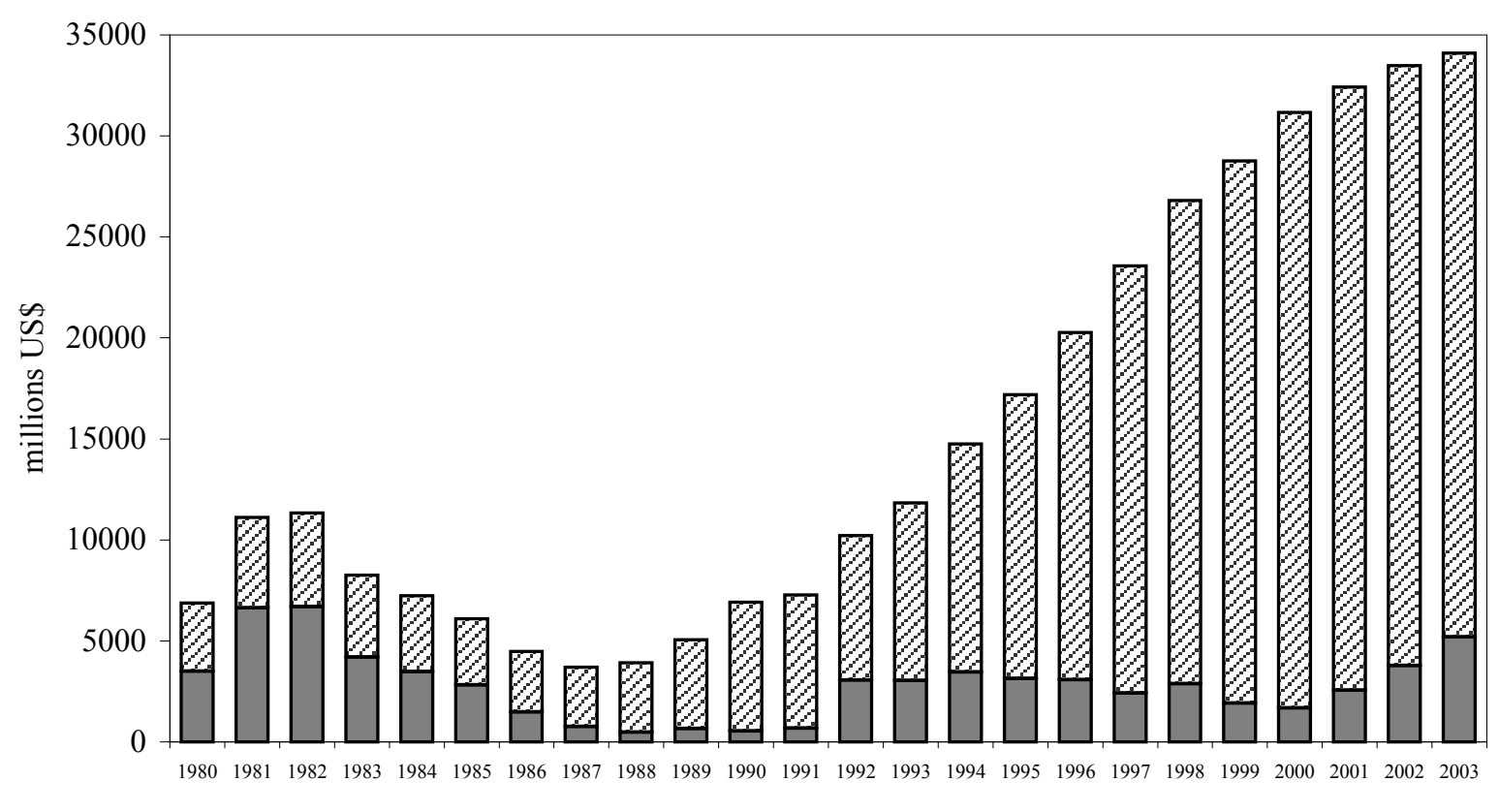

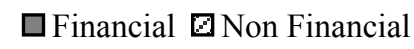

Figure 4: Foreign Liabilities

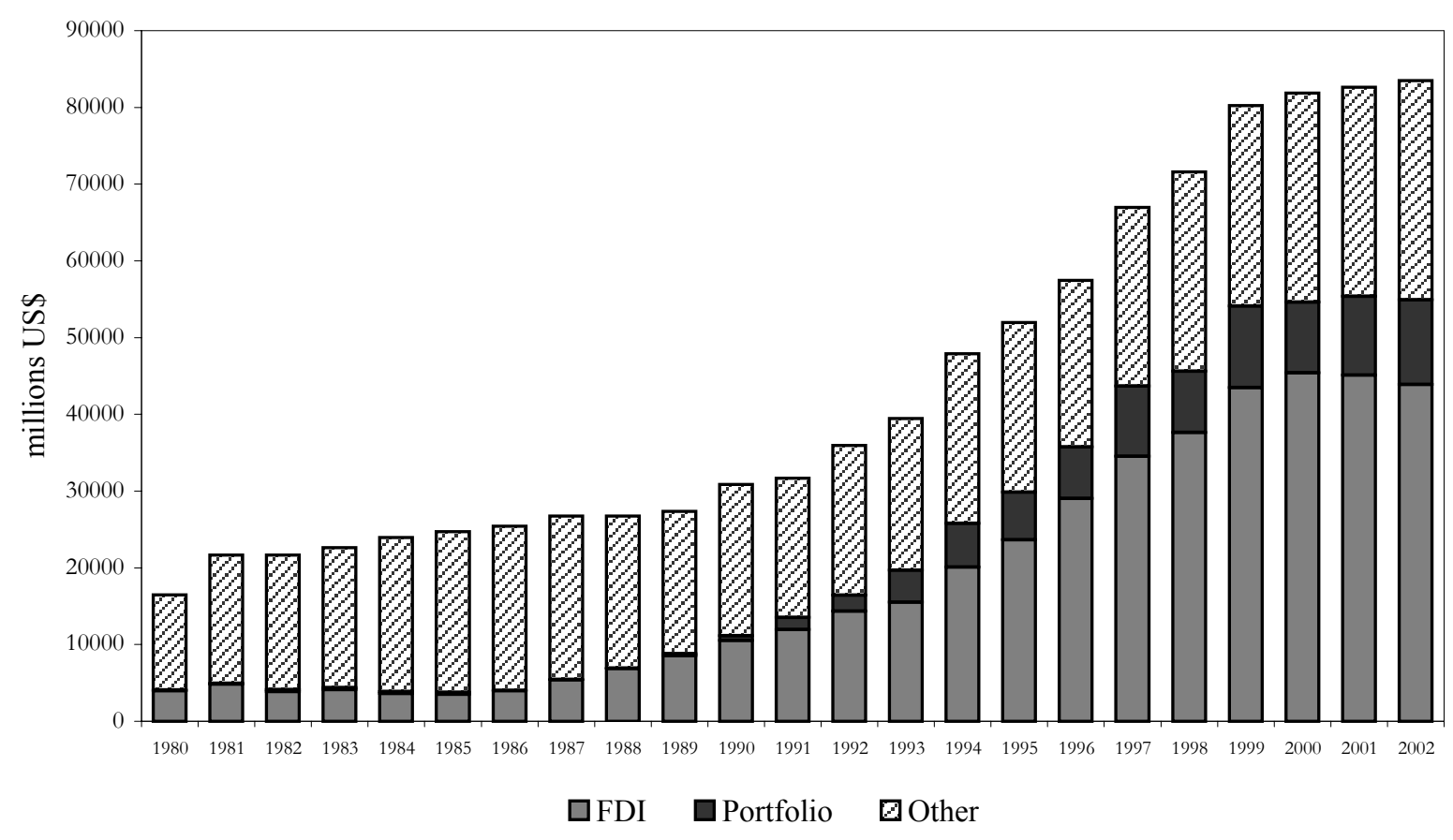

Source : Central Bank of Chile 


\section{Figure 5: International Investment Position}

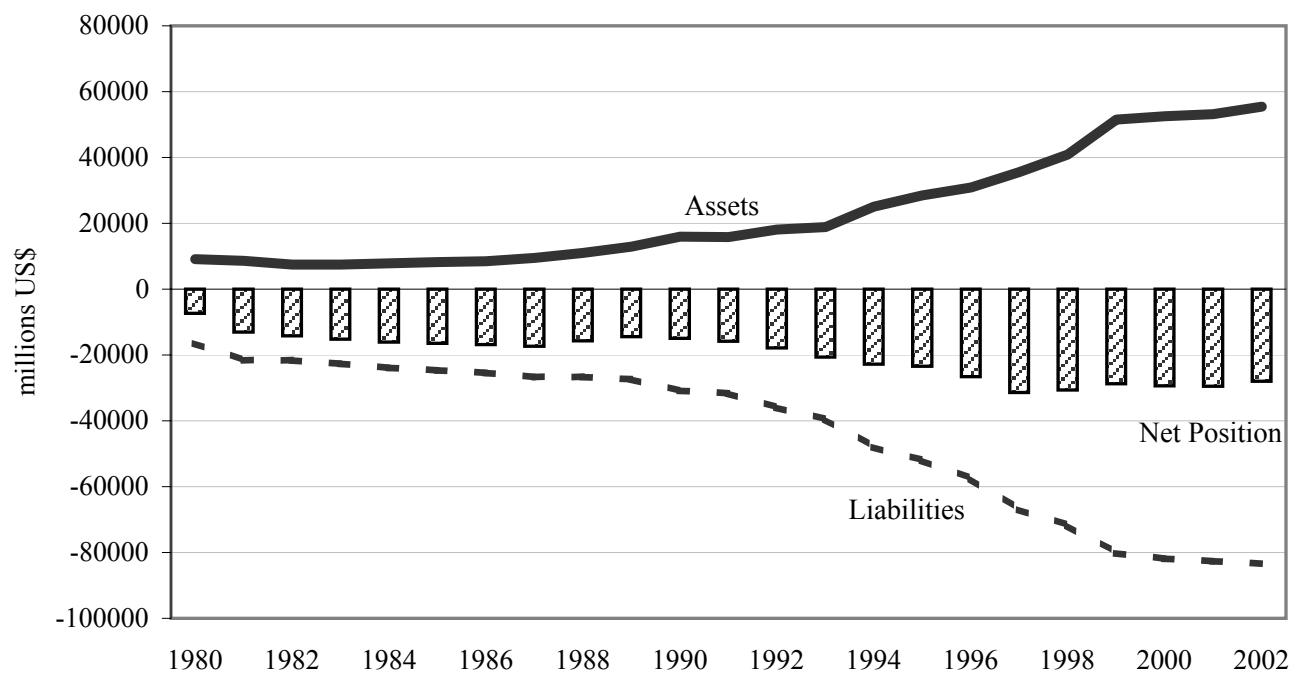

Figure 6: Foreign Assets in Pension Funds Portfolios

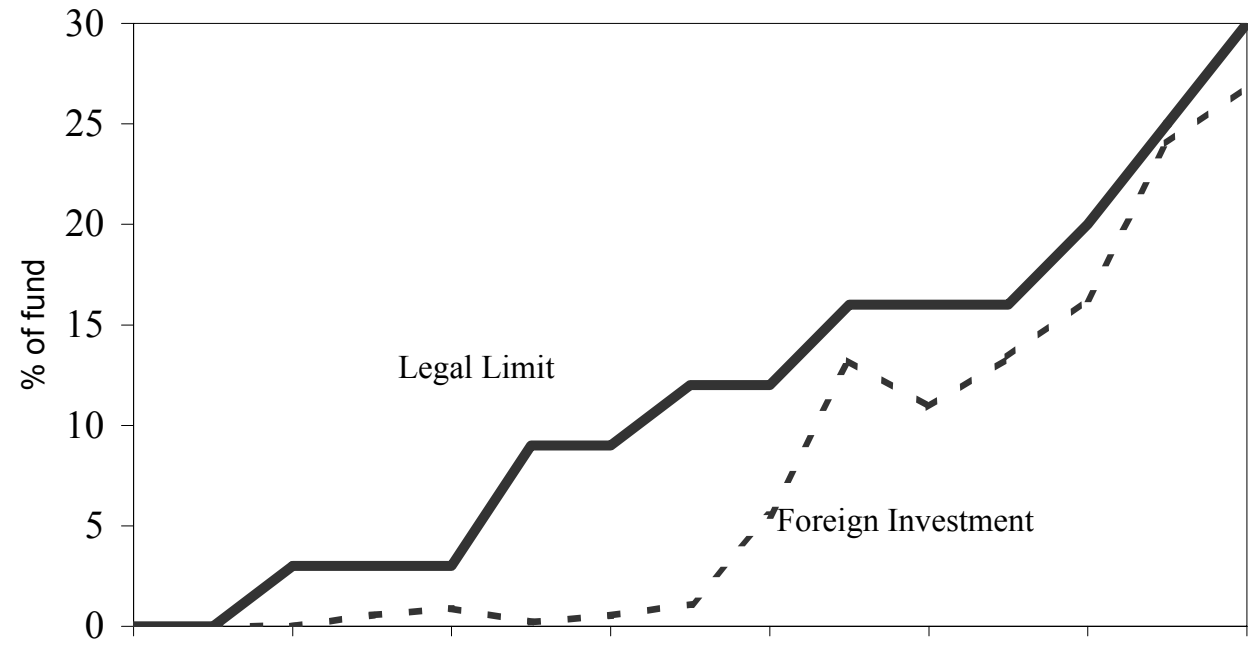

199019911992199319941995199619971998199920002001200220032004

Sources : Central Bank of Chile, Pension Fund Superintendency (SAFP). 
Figure 7

(a) Net Investment Position (\% GDP)

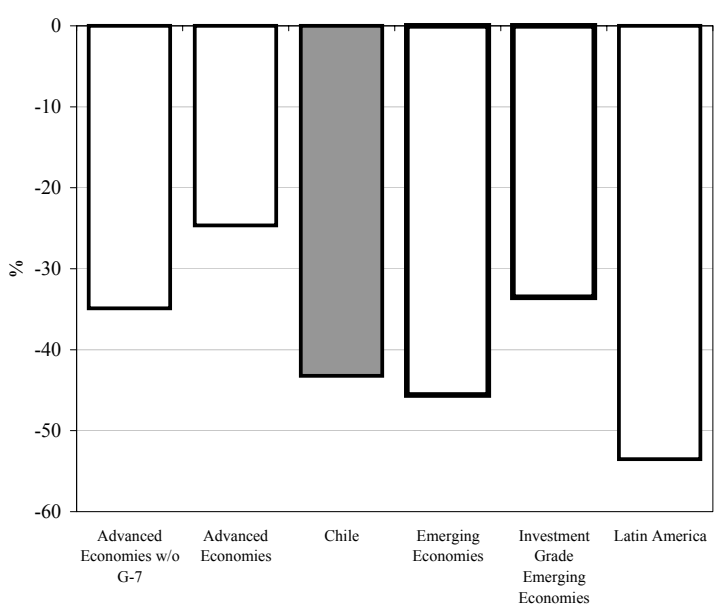

(c) Foreign Liabilities (\% GDP)

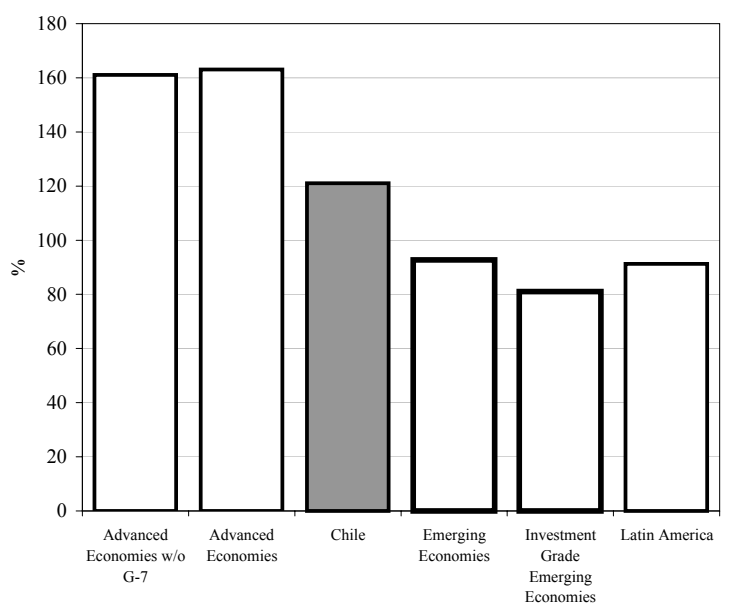

(b) Foreign Assets (\% GDP)

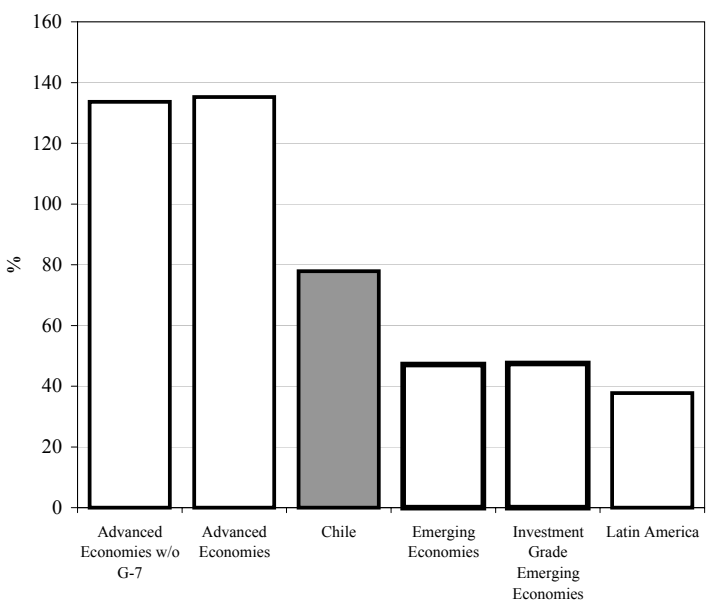

(d) international Financial Integration (\% GDP)

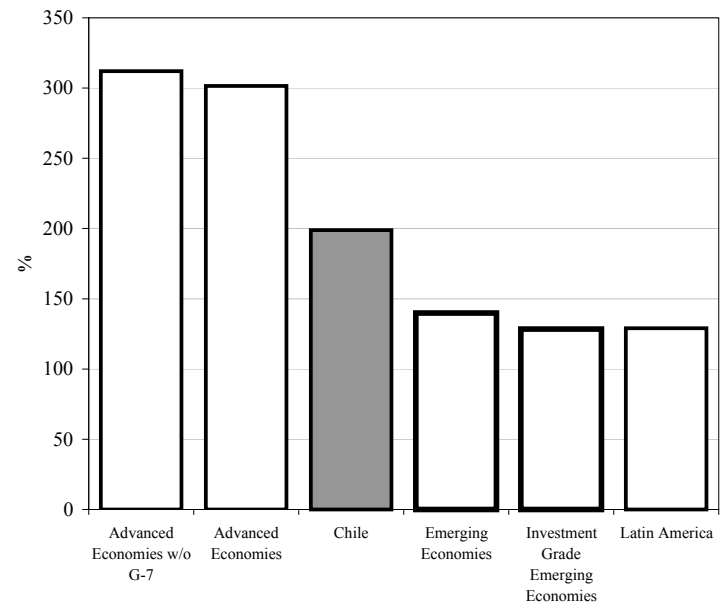

Source : Jadresic et al. (2003) 


\section{Figure 8: Nominal Exchange Rate}

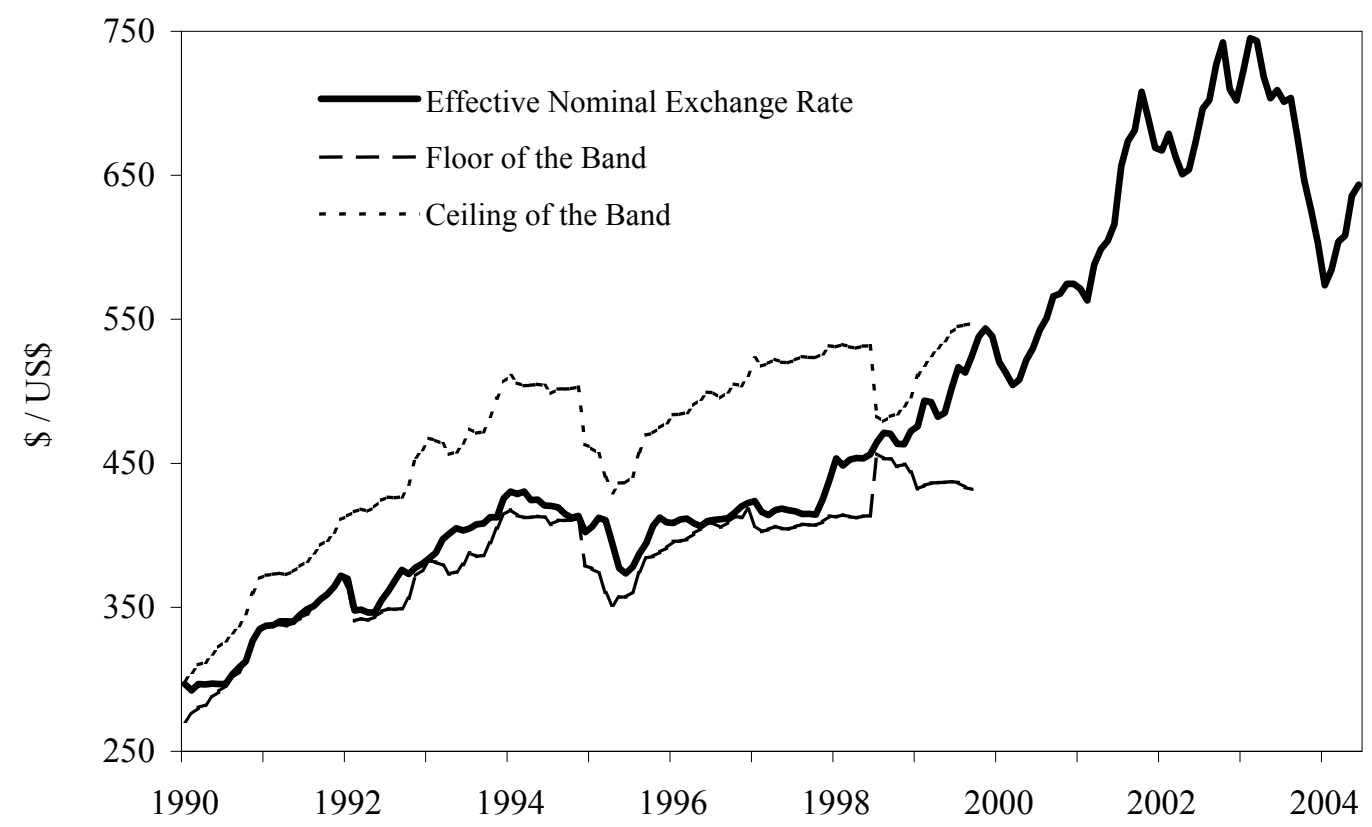

Figure 9: Real Exchange Rate $(1986=100)$

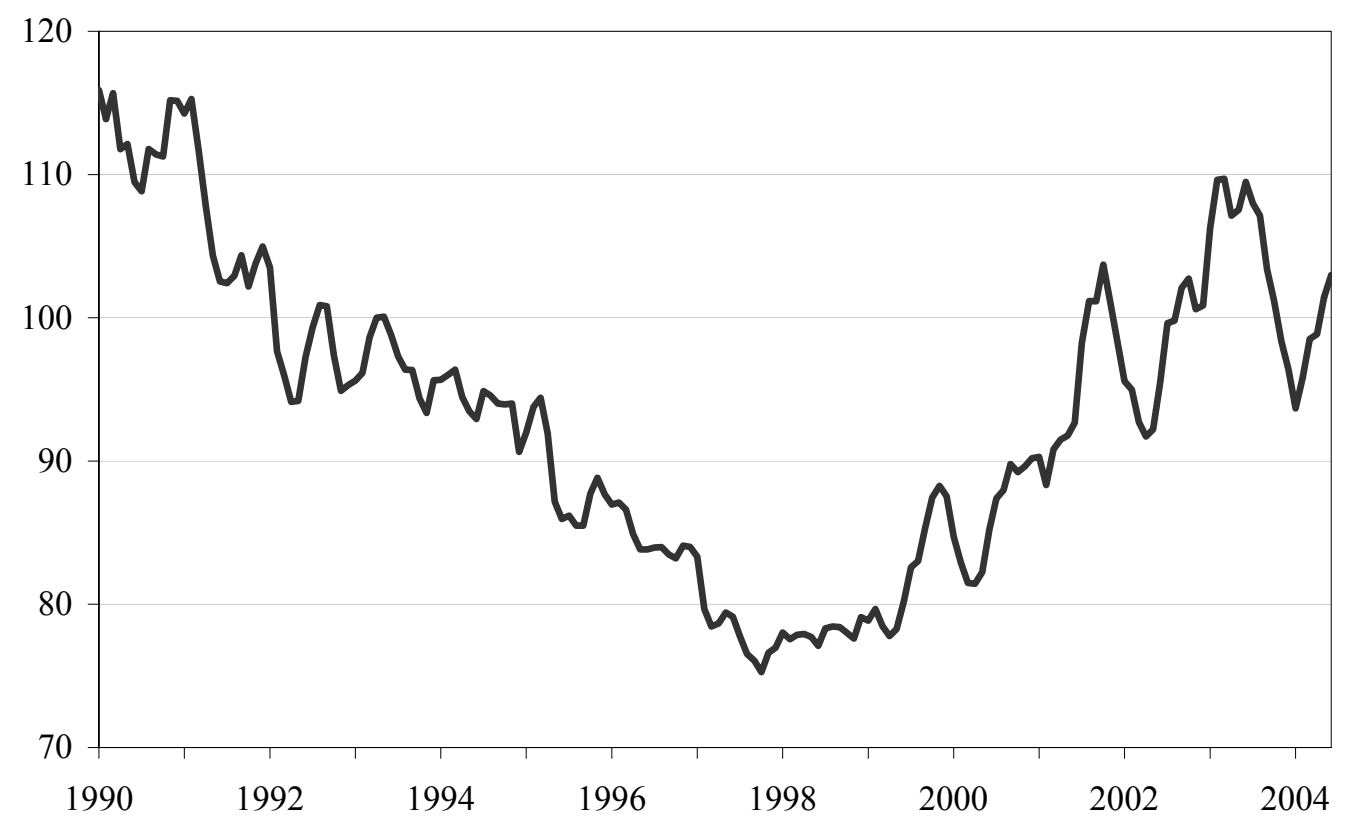

Source: Central Bank of Chile 
Figure 10: Currency Mismatch in the Banking System

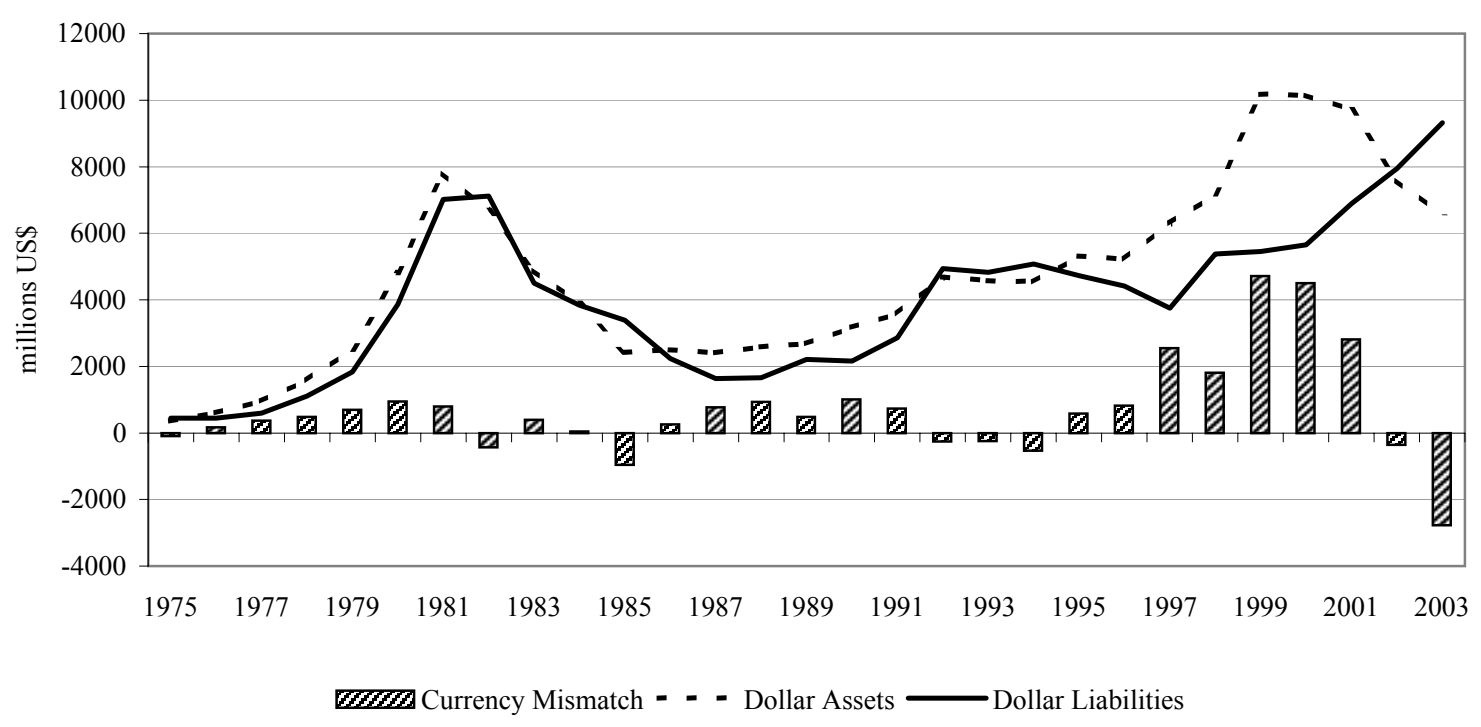

Source: Herrera \& Valdes (2004), Central Bank of Chile and IFS.

Figure 11: Composition of Total Liabitlies in the Banking Sector

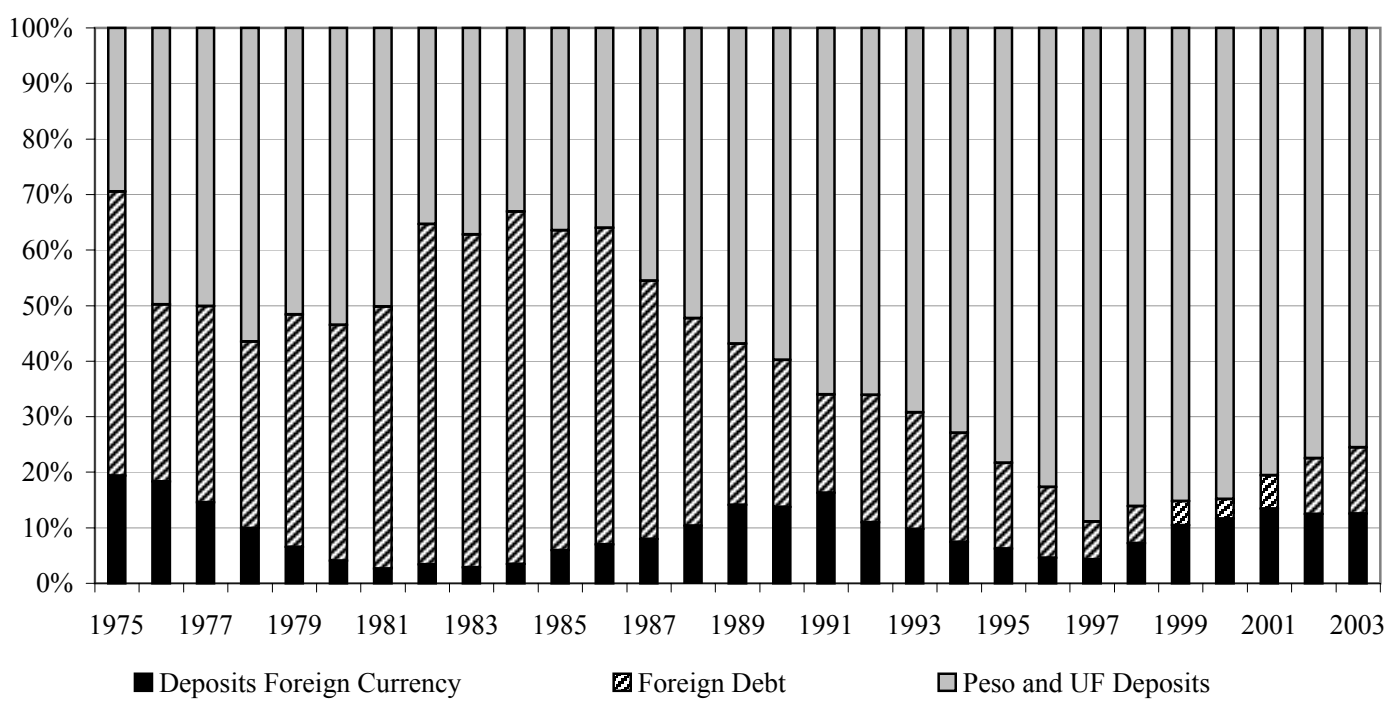

Source: Herrera \& Valdes (2004), Central Bank of Chile and IFS. 
Figure 12: Spreads

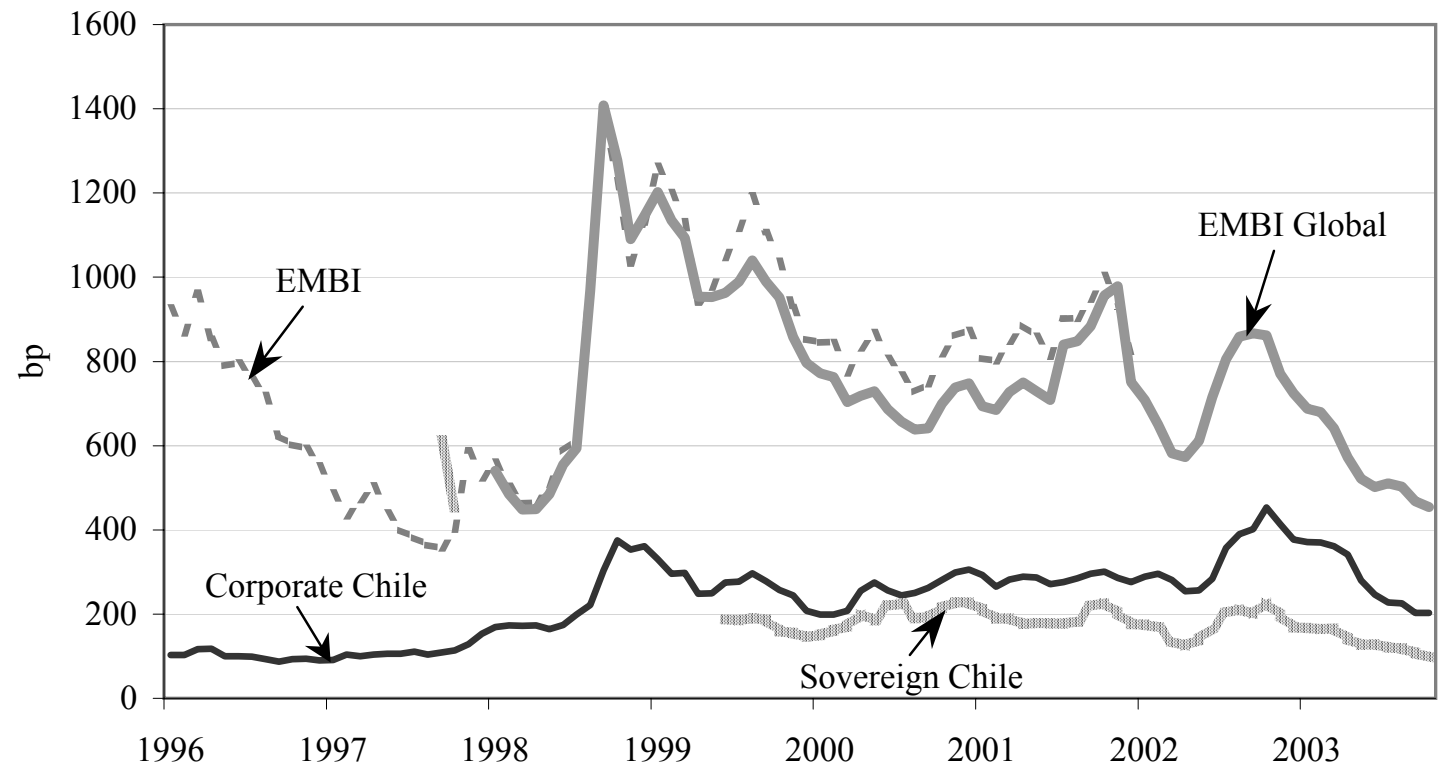

Sources: Merry Lynch and JP Morgan

Note : Sovereign Spread correspond to EMBI Global Chile 


\section{Figure 13 : Capital Flows}
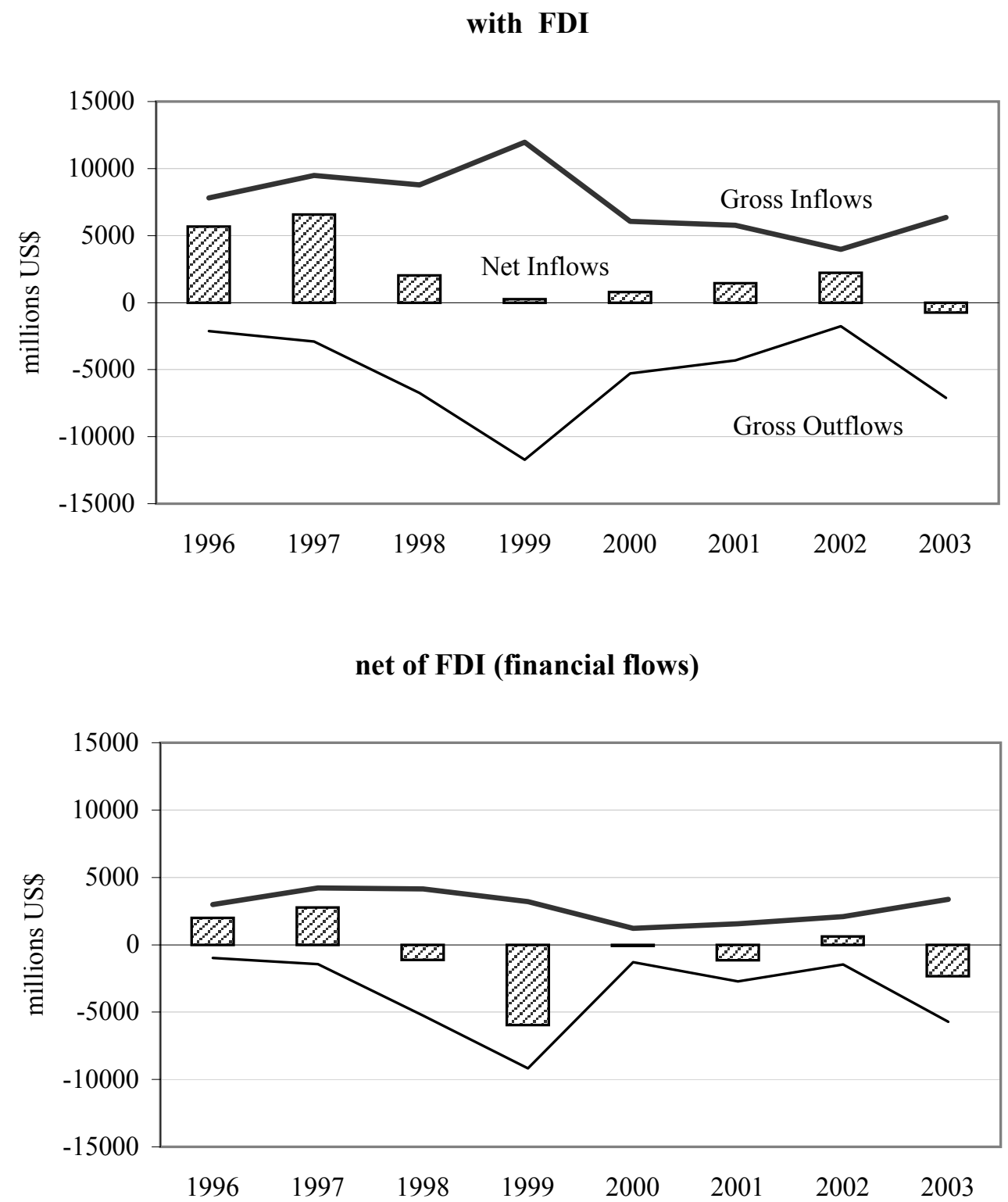

Source: IFS 


\section{Figure 14: Bank Assets and Currency Mismatches}

\section{Foreign Assets (\% Total Assets)}

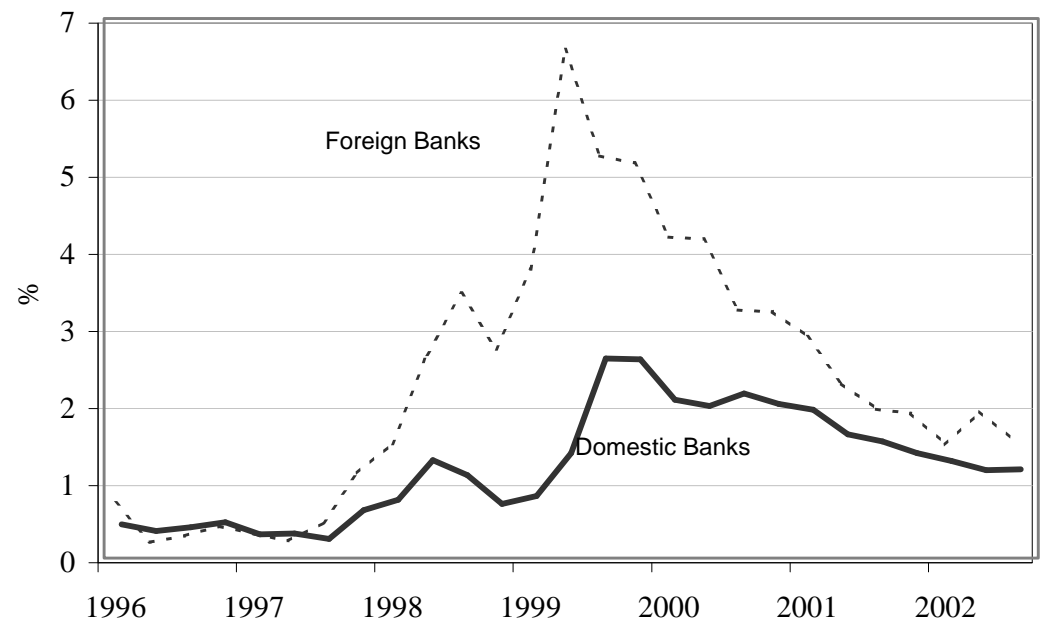

Sources: Caballero et al. (2004), Bank Superintendency and IFS.

Note: Dollar Assets were calculated as the sum of dollar denominated loans and foreign assets, and Dollar Liabilities as the sum of dollar denominated deposits and foreign liabilities. Foreign banks are those in which more that $50 \%$ of equity is owned by non-residents. Foreign assets are: cash in foreign currency, offshore deposits and offshore investments.

\section{Figure 15: International Reserves and Interest Rates 96-00}

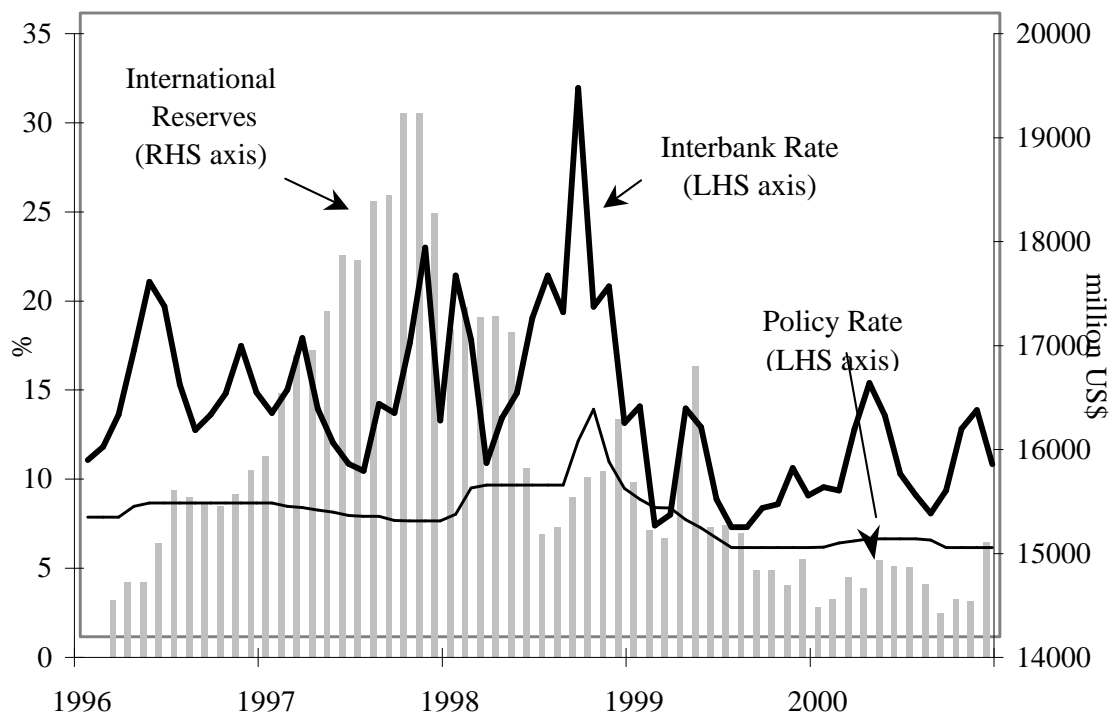

Source: Central Bank of Chile 
Figure 16: Current Account Deficit (\% GDP)

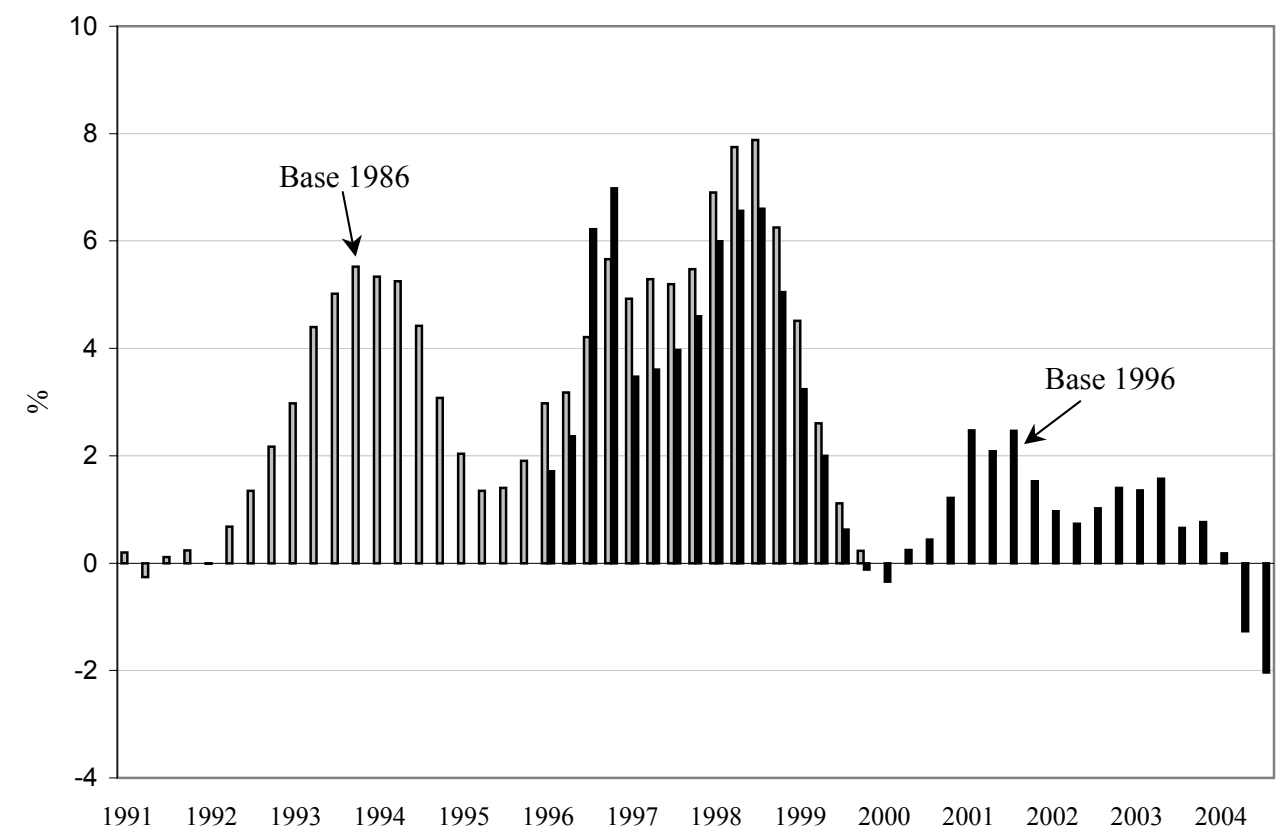

Source: Central Bank of Chile

Figure 17: Chilean GDP Growth and Unemployment Rate

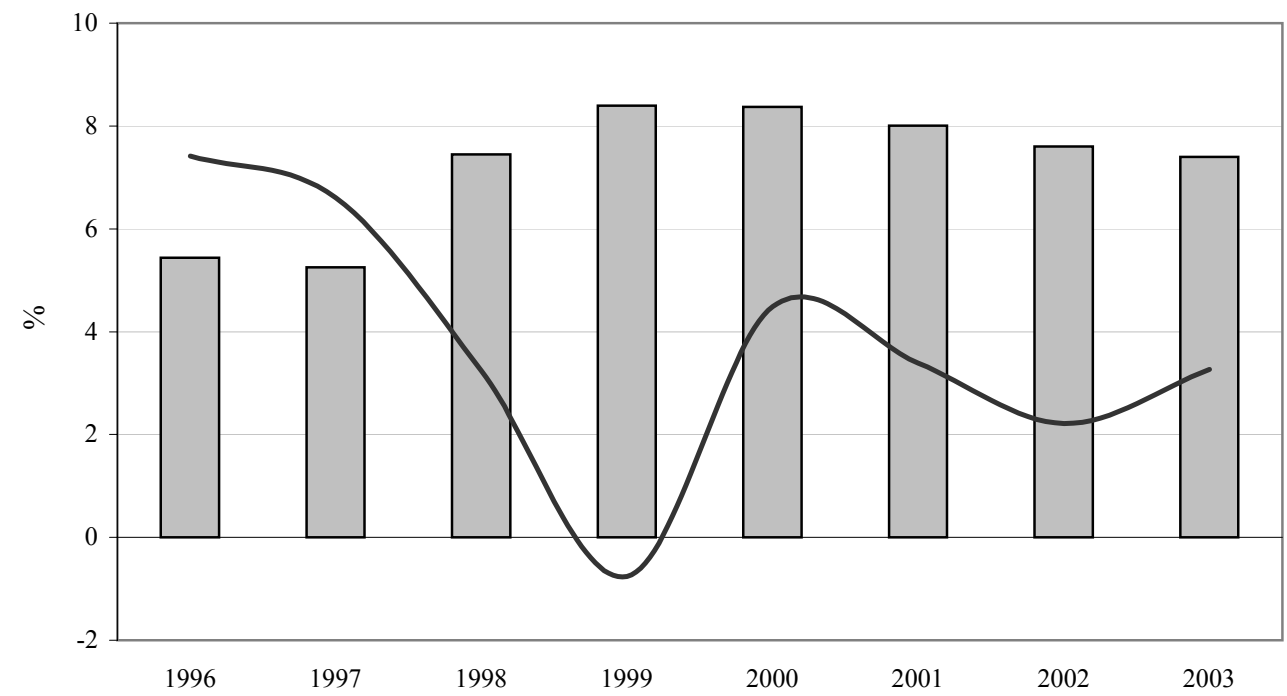

Source: Central Bank of Chile 